Article

\title{
Hydrogen as Future Energy Carrier: The ENEA Point of View on Technology and Application Prospects
}

\section{Mario Conte, Francesco Di Mario, Agostino Iacobazzi, Antonio Mattucci *, Angelo Moreno and Marina Ronchetti}

ENEA, Energy Technologies, Renewable Energy Sources and Energy Saving Dpt, C.R. Casaccia. Via Anguillarese, 301, 00123 S. M. di Galeria (Rome), Italy; E-Mails: francesco.dimario@enea.it; angelo.moreno@enea.it; marina.ronchetti@enea.it; agostino.iacobazzi@enea.it; mario.conte@enea.it

* Author to whom correspondence should be addressed; E-Mail: antonio.mattucci@enea.it; Tel.: +3906 30484394; Fax: +390630486315

Received: 16 February 2009; in revised form: 16 March 2009 / Accepted: 18 March 2009 / Published: 23 March 2009

\begin{abstract}
Hydrogen and fuel cells should reduce costs and increase reliability and durability to compete in the energy market. A considerable long term effort is necessary for research, development and demonstration of adequate solutions; important programs in this sense are carried out in the main industrialized countries, with the involvement of many industries, research structures and stakeholders. In such framework a relevant role is played in Italy by ENEA (Italian Agency for New Technologies, Energy and Environment). In the paper the main aspects related to the possible hydrogen role in the future society are addressed, according to ENEA perspectives.
\end{abstract}

Keywords: Hydrogen; fuel cell; energy scenario; hydrogen production; storage; hydrogen end-use.

\section{Introduction}

Hydrogen and fuel cells have received in the last years increasing attention, both at the international and Italian level, on the basis of their potential contribution to the development of a sustainable energy system in terms of emission reduction (both at global and local level), diversification of primary energy sources and industrial opportunities. Hydrogen, in fact, is an energy carrier that, although not available in nature, can be produced from different sources, both fossils and renewables, stored in a simpler way than electric energy and used in many applications, practically without harmful emissions 
to the environment. Fuel cells are the best technology for the use of hydrogen in transport and distributed power generation sectors, but can also use other fuels (natural gas, gas derived from coal, biomasses, wastes, etc.) with high efficiency and low environmental impact.

Wide-scale introduction of hydrogen and fuel cells in the energy market can take place in a medium-long term perspective and requires, on the one hand, the development of reliable and competitive technologies and, on the other hand, that a favorable context to foster more sustainable energy carriers and systems, which are normally more expensive than those presently available, is created.

Despite the fact that hydrogen is widely used in industry, its use as energy carrier requires that many barriers be overcome. These concern above all hydrogen production from both renewable and fossil sources with $\mathrm{CO}_{2}$ capture and storage (CCS), infrastructures for transport and distribution, storage on-board of vehicles and the development of adequate regulations, codes and standards.

Fuel cells, using both hydrogen and different fuels, should still reduce costs and increase reliability and durability to compete in the market of the innovative vehicles and generation/cogeneration energy systems. A considerable long term effort is necessary for research, development and demonstration of adequate solutions; important programs in this sense are carried out in the main industrialized countries, with the involvement of many industries, research structures and stakeholders. In such a framework, characterized by very promising perspectives, but also elements of uncertainty about the concrete development of the required technologies, a relevant role is played in Italy by ENEA (the Italian Agency for New Technologies, Energy and the Environment). In fact, ENEA promotes hydrogen technologies, in the framework of the actions carried out to face the challenges of emission reduction, higher use of renewable sources and energy efficiency improvement.

\section{Hydrogen and Fuel Cells Technologies}

Hydrogen is widely used in industry (about 50 million tons/year, corresponding to about $2 \%$ of the world consumption of energy), mostly in the oil refineries and chemical industry (only $5 \%$ of the hydrogen produced is commercialized for other applications, such as food and pharmaceutical industries). Hydrogen use as an energy carrier has substantially different requirements in comparison with the industrial uses, in terms of primary energy sources, environmental impact, costs, safety, and user acceptability. It is therefore required that the hydrogen technologies be improved or developed in terms of costs and energy efficiency (in the following paragraphs they are respectively expressed in $€$ 2008 and based on LHV).

\subsection{Hydrogen Production}

Hydrogen exists in nature only in combination with other elements (with oxygen in water; carbon and oxygen in organic materials and fossil fuels) and is produced from its compounds, using energy sources. The benefits deriving from the hydrogen use depend, to a large extent, from the specific features of the production processes. In short, the use of hydrogen supports the development of a new more sustainable energy system, with higher diversification of primary sources and reduction of greenhouse gas emission, on condition that in the long term it can be produced through sustainable 
processes. Hydrogen can be obtained from a wide variety of sources, such as fossil fuels, biomasses, water, etc., with different production processes, as shown in Figure 1.

Figure 1. Hydrogen Production Processes.

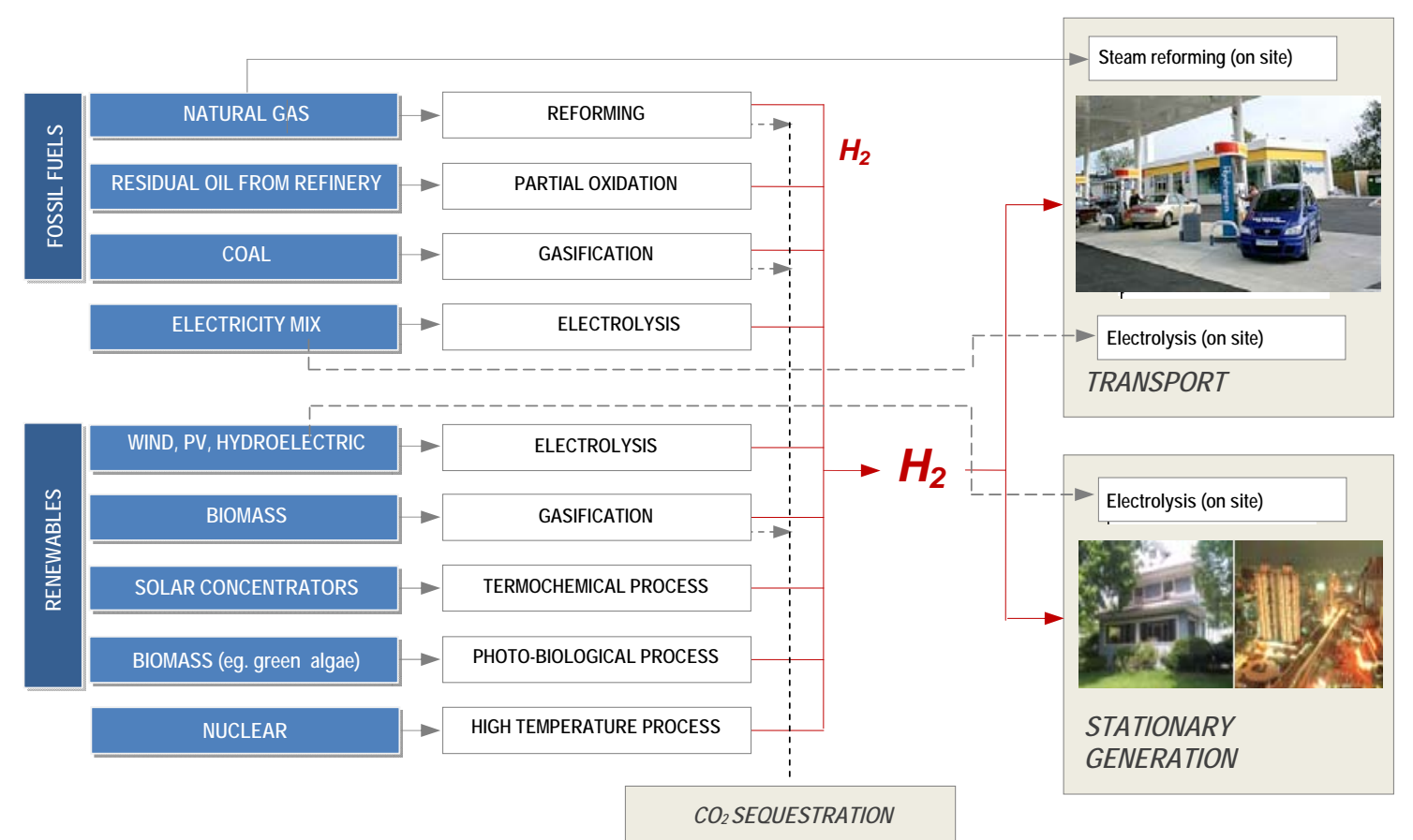

Depending on the type of process, the production can take place at centralized level, in large-scale plants, or at distributed level, in small size plants located near the end-user. Distributed production can represent the most viable option to make possible the hydrogen use in the short-medium term, as it requires less investments and infrastructures for transport and distribution; centralized production can instead guarantee, when the hydrogen demand grows, reduced costs and, in case of production from fossil fuels, lower environmental impact (CCS option can be economically viable only in centralized plants).

\subsubsection{Production from Fossil Fuels}

Hydrogen production technologies from fossil fuels (steam reforming, partial oxidation, gasification) are mature and widely used (presently they provide more than $95 \%$ of the hydrogen produced), even if they need to be optimized, for large-scale production, from the point of view of energy efficiency, environmental impact and, above all, costs. Furthermore, depending on the process and primary source used, the production from fossil sources, to be sustainable in the medium-long term, should be coupled with capture and storage of the co-produced $\mathrm{CO}_{2}$. The development of solutions for cost-effective and reliable CCS is an essential condition in the long-term not only to produce hydrogen from fossil sources but, in general, to make possible the use of fossil fuels in a way compatible with the environment. 


\section{Production from Hydrocarbons}

At present about $78 \%$ of hydrogen is produced from natural gas (48\%) and other hydrocarbons (30\%). The most economically advantageous and used process is the catalytic steam reforming of natural gas (but also liquefied petroleum gas or naphtha can be used in the process). Possible improvements of the process are mainly focused on recovery of thermal energy, process integration and gas purification.

The typical capacities of industrial plants range between 100,000 and $250,000 \mathrm{Nm}^{3} / \mathrm{h}$, with thermal efficiencies of about $80 \%$. Medium (200-500 Nm $3 / \mathrm{h})$ and small $\left(50-300 \mathrm{Nm}^{3} / \mathrm{h}\right)$ capacity plants are suitable for specific industrial applications, with reduced efficiencies and higher costs per product unit. Systems of lower capacity $\left(1-50 \mathrm{Nm}^{3} / \mathrm{h}\right)$ have been developed for integration with fuel cells and are currently used in hydrogen refueling stations; in this case, further improvements are needed, mainly related to the integration of different equipment, gas purification and study of innovative catalysts [1]. For heavier hydrocarbons, auto-thermal reforming or partial oxidation processes with thermal efficiencies higher than $75 \%$ are used.

Together with the most mature processes other technologies exist, presently less used or under development, such as:

- Thermal or catalytic cracking of methane, that converts methane in hydrogen and carbon, without $\mathrm{CO}_{2}$ production;

- Sorption Enhanced Reaction process, that combines in the same reactor the reactions of steam reforming and shift with $\mathrm{CO}_{2}$ separation (through absorption in suitable materials);

- Solar steam reforming, where concentrated solar energy is utilized as heat source for the reforming reaction.

The cost for hydrogen produced through steam reforming strongly depends on the plant size and the cost of natural gas (for large plants it represents 50-70\% of the final cost). The increase of price of the natural gas has determined in the last years a sensible increase of the hydrogen cost, ranging, in large size plants, from $5 \div 6 € / G J$ (with gas price of $3 € / G J$ ) to more than $8 € / G J$ (with gas price of about 6 $€ / G J)$. If CCS is included in such plants, together with a further increase of the natural gas price, a cost higher than $11 € / G J$ is estimated in 2020. For small-size plants the hydrogen cost is presently around $20 € / G J$; in 2020, taking into account the possible technology optimization and the increase of natural gas price, a slightly higher cost is expected [2-4].

\section{Coal Gasification}

At the present time, about $18 \%$ of the hydrogen produced worldwide is derived from coal gasification, in large-scale central facilities $\left(100,000-200,000 \mathrm{Nm}^{3} / \mathrm{h}\right)$. Substantially three types of gasifiers are available: moving (or fixed) bed, fluidized bed and entrained flow.

The overall efficiency is about $60-65 \%$, with a reduction of $3-6 \%$ points in plants where $\mathrm{CO}_{2}$ capture and storage is provided. The technology is mature, even if it is more complex and less consolidated than steam reforming. The potential for further improvements is still considerable and takes into account innovative membranes for air separation, progress in gasifier configuration, hot gas purification systems, new solvents and membrane reactors for hydrogen separation, etc. Coal gasification, integrated into combined cycles with CCS, represents also a very interesting option for 
centralized cogeneration of electric energy and hydrogen. Such plants will have specific costs equivalent to those of similar plants designed only for electric energy generation and hydrogen costs equal or less than those of hydrogen production plants [5].

The complexity of hydrogen production systems from coal implies investment costs higher than natural gas steam reforming, only partially counterbalanced by lower fuel costs. Therefore higher hydrogen costs are expected. In literature costs ranging between 8 and $10 € / G J$ are found, for coal price in the range from 1.5 to $2 € / G \mathrm{~J}$; presence of CCS imposes a significant increase of the plant cost (15-20\%), with the hydrogen cost increasing to 10-12 €/GJ [2-4]. The cost difference between hydrogen produced from natural gas and coal could be lower in future, both because coal gasification has larger margins of improvement in the medium term, compared with steam reforming, and coal cost could be subject to cost rises lower than the ones of natural gas.

\subsubsection{Production from Water Electrolysis}

Electrolysis [6] allows the splitting of water in its constituents, hydrogen and oxygen, using electric energy. The process has, at the present state, significantly higher costs than hydrogen production from fossil fuels and covers only a small share of the world production (4\%). The process is mostly used to satisfy requests for high purity hydrogen. There are many technologies available and under development (Table 1). The electrolysers on the market are essentially of two types: alkaline electrolysers, that use an aqueous solution of potassium hydroxide $(\mathrm{KOH})$, and solid polymer electrolysers, where the electrolyte is a polymer membrane (the same as the polymer electrolyte fuel cells).

Table 1. Characteristics of Different Electrolyser Technologies [7].

\begin{tabular}{|c|c|c|c|c|c|}
\hline \multirow[b]{2}{*}{ Technology } & \multicolumn{2}{|c|}{ Alkaline electrolysers } & \multirow{2}{*}{$\begin{array}{c}\text { Inorganic } \\
\text { membrane } \\
\text { electrolyser }\end{array}$} & \multirow{2}{*}{$\begin{array}{c}\text { Solid polymer } \\
\text { electrolyser } \\
\text { (PEM) }\end{array}$} & \multirow{2}{*}{$\begin{array}{c}\text { High } \\
\text { temperature } \\
\text { electrolyser } \\
\text { (HTE) }\end{array}$} \\
\hline & Conventional & Advanced & & & \\
\hline Development stage & $\begin{array}{l}\text { Commercial } \\
\text { large-scale } \\
\text { plant }\end{array}$ & $\begin{array}{c}\text { Prototypes and } \\
\text { commercial } \\
\text { units }\end{array}$ & $\begin{array}{l}\text { Commercial } \\
\text { units }\end{array}$ & $\begin{array}{c}\text { Prototypes and } \\
\text { commercial units }\end{array}$ & $\begin{array}{l}\text { Laboratory } \\
\text { stage units }\end{array}$ \\
\hline Electrolyte & $25-35 \% \mathrm{KOH}$ & $25-40 \% \mathrm{KOH}$ & $14-15 \% \mathrm{KOH}$ & $\begin{array}{c}\text { Nafion } \\
\text { membrane }\end{array}$ & $\mathrm{Y}_{2} \mathrm{O}_{3}+\mathrm{ZrO}_{2}$ \\
\hline Temperature, ${ }^{\circ} \mathrm{C}$ & $70-90$ & $80-145$ & $90-120$ & $80-150$ & $900-1000$ \\
\hline Pressure, bar & $1-2$ & Up to 120 & Up to 40 & Up to 400 & Up to 30 \\
\hline $\begin{array}{l}\text { Energy consumption, } \\
\text { kWh/Nm}{ }^{3} \mathrm{H}_{2}\end{array}$ & $4.3 \div 4.9$ & $3.8 \div 4.3$ & 4.8 & $3.6-4.0$ & $2.5-3.5$ \\
\hline
\end{tabular}

Alkaline electrolysers represent a well-established and utilized technology, even if further RD\&D is needed to reduce costs (current cost are $800-1,500 € / \mathrm{kW}$ ) and increase their efficiency (presently is 40 $60 \%$ auxiliary included) and lifetime. Significant improvements have been already obtained in advanced alkaline electrolysers, available as prototypes, which work at higher temperatures and 
pressures. The solid polymer electrolysers present some advantages (absence of corrosive liquids, higher current density and operating pressures), but have durability problems (particularly for the limited lifetime of some membranes).

An interesting line of development, in a medium-term perspective, is high temperature electrolysis (800-1,000 ${ }^{\circ} \mathrm{C}$ ), where high temperature heat can be used effectively to decrease the amount of electrical energy (up to $40 \%$ ) needed to produce the hydrogen. The technology is similar to the one of solid oxide fuel cells and the necessary heat can be provided from industrial, nuclear or solar processes. The expected cost varies between 800 and $1,000 € / \mathrm{kW}$, with efficiencies of $80 \%$ and commercial availability in 2020.

The factor that mostly influences the hydrogen cost is the system efficiency, considering that the electric energy cost represents, for plant of significant sizes, about $80 \%$ of the hydrogen cost. It is estimated that, for large size plants, the hydrogen cost from electrolysis could be reduced from $30 € / G \mathrm{~J}$ in 2010 to $15 € / G J$ in 2030 (with an electricity price of $0.03 € / \mathrm{kWh}$ ) [7]. Lower values could be achieved using off-peak electricity. Electrolysers, thanks to their modularity, are suitable both for hydrogen distributed production and, in perspective, centralized production. It is clear that sustainability of the process depends on the primary source used to produce electric energy. The most favorable option from this point of view is the one that foresees the coupling with renewable sources, such as photovoltaic and wind. This option can have sense in special situations (remote plants) or in presence of an electricity surplus from renewable sources that makes appropriate the use of hydrogen as electricity storage medium. The cost of renewable hydrogen production is presently a lot higher than the one from electric grid, even if a significant reduction can be expected in the medium term.

\subsubsection{Production from Renewables}

\section{Hydrogen from Biomasses}

Hydrogen can be produced from biomasses using different thermochemical (gasification, pyrolysis) and biological processes. Among the thermochemical processes, in general more suitable for centralized production, most attention is focused on gasification. The process is similar to that used to produce hydrogen from coal (with which the biomass can also be co-gasified), even if the plant sizes are smaller. The biomass can have different origin, such as agricultural and forest residues, industrial and urban wastes, organic waste materials, etc.

Some pilot plants are currently in the demonstration phase; improvements are required to increase reliability and reduce process costs. In addition better biomass logistics are needed. The hydrogen cost depends on plant size and feedstock costs and can assume values in the range of 10-25 €/GJ [2-4].

The anaerobic digestion of organic materials is at the moment the most promising biological process for hydrogen production. This process, tested at laboratory scale, has a theoretical specific reactor yield of $10-20 \mathrm{~m}^{3} /$ day of hydrogen and a substrate consumption of about $20-100 \mathrm{~kg} / \mathrm{m}^{3} /$ day. The technology offers considerable potentials, but a large research effort is still needed to understand and optimize the whole process in order to proceed to its scale-up [8].

Concerning hydrogen production from biomasses, it is necessary to consider that such process is in competition with other possible biomass uses, both of conventional (combustion for production of electric energy and heat) and non-conventional type (biofuel production; direct use of gas in high 
temperature fuel cells). These competing alternative uses must be taken into account in evaluating potential and perspectives of this specific chain.

\section{Hydrogen from Water Through Thermochemical Cycles}

Thermochemical cycles consist in splitting water into hydrogen and oxygen through a set of chemical reactions involving intermediate compounds that are fully recycled at the end of the process. Such cycles operate at temperatures lower than the ones of direct water thermolysis $\left(\mathrm{T}>2,000{ }^{\circ} \mathrm{C}\right)$ and, in theory, without electric energy contributions. The required heat can be supplied from solar or nuclear sources and the efficiencies are estimated about 40-50\%, higher than water electrolysis, if the efficiency of electricity production is taken into consideration.

To date, over 200 thermochemical cycles have been investigated, mostly at theoretical level, while only a few have been selected to test their technical feasibility. The most interesting processes are listed in Table 2.

Table 2. Some Thermochemical Production Processes [9].

$\begin{array}{llc}\text { Thermochemical cycle } & \text { Reaction } & \text { Temperature } \\ & \left({ }^{\circ} \mathrm{C}\right)\end{array}$

The sulfur-iodine is one of the most promising cycles currently under evaluation; it has been demonstrated with a production of about $30 \mathrm{NL} / \mathrm{h}$ of hydrogen. For this cycle a laboratory scale testing campaign is expected in the next years (within 2010) at General Atomic (San Diego, CA, USA) in the framework of an international project. Important activities in this field are also carried out in Europe, from research structures such as CEA, DLR, CIEMAT and ENEA.

Critical issues of the process are the separation of the hydrogen produced and the problems of corrosion associated with the chemicals involved in the cycle. Because of their complexity, thermochemical processes are considered for centralized hydrogen production, coupled with IV generation nuclear energy plants or with concentration solar systems. The technology development still requires considerable research efforts and the availability of commercial systems can be expected from 2030 onwards. Hydrogen cost is estimated between 10 and $20 € / G J$ using nuclear energy and almost doubles for solar [10-12]. 


\section{Other Advanced Processes}

Photo-electrochemical production - A photo-electrochemical system combines in the same device both electric energy generation from solar light and its utilization to produce hydrogen from water through an electrolyser. This device uses a semiconductor, immersed in aqueous solution, which directly converts solar light into chemical energy. It is therefore a potentially very promising process, as it can reach considerably lower costs and higher efficiencies than a photovoltaic electrolysis system. Different concepts are studied at laboratory level, with interesting results (solar-hydrogen efficiencies up to $16 \%$ ), but considerable $\mathrm{R} \& \mathrm{D}$ efforts on materials and system engineering are needed to reach the technical and commercial maturity, that can be expected only in the long-term.

Photo-biological production -The hydrogen can be produced from water using sunlight and photosynthetic microorganisms. The process has reached, at laboratory scale, interesting conversion efficiencies (about $2 \%$ of the incident light radiation), even if it still requires important improvements, both to understand the basic mechanisms of process and for its scale-up. Photo-biological water splitting is a long-term technology.

\subsubsection{Summary of Production Technologies}

Table 3 provides a synthesis of the different technologies of hydrogen production.

Table 3. Overview of Hydrogen Production Processes.

\begin{tabular}{|c|c|c|c|c|c|c|c|}
\hline \multirow{2}{*}{ TECHNOLOGY } & & \multirow{2}{*}{$\begin{array}{l}\text { Development } \\
\text { stage }\end{array}$} & \multirow{2}{*}{$\begin{array}{c}\mathrm{CO}_{2} \\
\text { emissions }\end{array}$} & \multicolumn{2}{|c|}{ Production type } & \multicolumn{2}{|c|}{ Production cost ( $€ / G J)$} \\
\hline & & & & Distributed & Centralized & Today & Future \\
\hline \multirow{3}{*}{$\begin{array}{l}\text { Natural gas steam } \\
\text { reforming }\end{array}$} & \multirow[t]{2}{*}{ no CCS } & \multirow{2}{*}{$\begin{array}{l}\text { Commercial } \\
\text { plants }\end{array}$} & \multirow[t]{2}{*}{ Medium/High } & & $\checkmark$ & 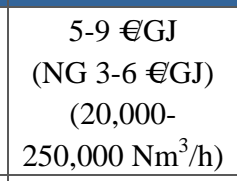 & \\
\hline & & & & $\checkmark$ & & $\begin{array}{c}19-22 € / \mathrm{GJ} \\
(<20,000 \\
\left.\mathrm{Nm}^{3} / \mathrm{h}\right)\end{array}$ & $\begin{array}{c}21-25 € / G J \\
N G 6 € / G J \\
(2020)\end{array}$ \\
\hline & with CCS & $\begin{array}{l}\text { Prototypes in } \\
\text { development }\end{array}$ & Low & & $\checkmark$ & 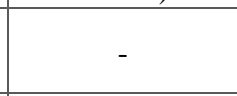 & $\begin{array}{c}11-12 € / G J \\
(2020)\end{array}$ \\
\hline \multirow[b]{2}{*}{ Coal gasification } & no CCS & $\begin{array}{c}\text { Commercial } \\
\text { plant }\end{array}$ & High & & $\checkmark$ & $\begin{array}{c}8-10 € / \mathrm{GJ} \\
\text { (Coal } 1.5-2 € / \mathrm{GJ})\end{array}$ & - \\
\hline & with CCS & $\begin{array}{l}\text { Prototypes in } \\
\text { development }\end{array}$ & Low & & $\checkmark$ & - & $\begin{array}{c}10-12 € / G J \\
\text { Coal } 2 € / G J \\
(2020)\end{array}$ \\
\hline Biomass gasification & & Pilot plants & Low & $\checkmark$ & $\checkmark$ & $10-25 € / G J$ & $\begin{array}{c}10-20 € / G J \\
(2020)\end{array}$ \\
\hline Biological processes & & Lab stage & Low & & $\checkmark$ & - & - \\
\hline
\end{tabular}


Table 3. Cont.

\begin{tabular}{|c|c|c|c|c|c|c|c|}
\hline \multicolumn{2}{|c|}{$\begin{array}{l}\text { Electrolysis } \\
\text { Electricity from electric grid }\end{array}$} & $\begin{array}{l}\text { Commercial } \\
\text { units }\end{array}$ & $*$ & $\checkmark$ & $\checkmark$ & $\begin{array}{c}25 € / \mathrm{GJ} \\
(\mathrm{EE} 0.025 \\
€ / \mathrm{kWh}) \\
200 € / \mathrm{GJ} \\
(\mathrm{EE} 0.20 \\
€ / \mathrm{kWh}) \\
\end{array}$ & $\begin{array}{c}15-30 € / \mathrm{GJ} \\
\text { EE } 0.03 \\
€ / \mathrm{kWh}(2030)\end{array}$ \\
\hline \multirow{2}{*}{$\begin{array}{l}\text { Thermochemical } \\
\text { cycles }\end{array}$} & solar & R\&S stage & Zero & & $\checkmark$ & - & $\begin{array}{c}20-30 € / G J \\
(2030)\end{array}$ \\
\hline & nuclear & R\&S stage & Zero & & $\checkmark$ & - & $\begin{array}{c}10-20 € / G J \\
(2030)\end{array}$ \\
\hline
\end{tabular}

* The $\mathrm{CO}_{2}$ emissions are those produced in the electric energy generation phase

\subsection{Hydrogen Storage}

The utilization of storage systems is necessary in different phases of the hydrogen cycle (production, service station, on-board vehicles). The availability of suitable storage systems represents one of the biggest hurdles to a widespread use of hydrogen, mainly in the transport sector. In this case vehicular design, weight, size, volume and efficiency strongly affect the amount of hydrogen that can be stored on-board.

The problems related to the hydrogen storage derive from its chemical-physical characteristics. Hydrogen is a fuel that has a high gravimetric energy density, but also low volumetric energy density, both at gaseous and liquid state. Consequently it is clear that, compared to other fuels, hydrogen requires higher volume tanks to store the same energy content.

In particular, the hydrogen storage systems for vehicular applications need to meet specific technical and economic requirements and safety standards that allow hydrogen vehicles to have similar driving range and performance as vehicles using conventional liquid fuels.

The storage system should have high density of energy (corresponding to high amounts of stored hydrogen), high density of power, good energy efficiency, low boil-off losses in liquid hydrogen storage, adequate life-cycle, reduced or no environmental impact and acceptable safety features (both during operation and in the phases of manufacture and disposal at end of life), reduced costs and should allow efficient and fast and safe filling at the refueling station.

Different technologies are already in use or under development for hydrogen storage. It can be stored as high pressure gas, in liquid or chemical form, absorbed/adsorbed on special materials (metallic hydrides, chemical hydrides, carbon nanostructures). Each technology shows advantages and limitations, but all of them, even where they are already applied, require still significant R\&D efforts for a reliable and competitive large scale use. The current ambitious research targets aim to develop and demonstrate hydrogen storage systems achieving $2 \mathrm{kWh} / \mathrm{kg}\left(6 \mathrm{wt} \% \mathrm{H}_{2}\right)$ by 2010 and $3 \mathrm{kWh} / \mathrm{kg}(9$ wt\% $\mathrm{H}_{2}$ ) by 2015 [13].

These technical objectives (added to the energy and economical ones) have remarkably widened the set of solutions and materials studied with the support of public funding; in the U.S. Department of Energy Program about 30-35 M€ have been provided, while the European Commission invested in total about $25 \mathrm{M} €$ only in the Sixth Framework Program. 
Figure 2 shows the status of vehicular hydrogen storage systems in comparison with 2010 and 2015 DoE targets [14]. It can be seen that none of the current systems meet the proposed gravimetric and volumetric targets and that the distance to achieving them is still large.

It is however necessary to consider that hydrogen storage requires use of energy; in particular, in order to store hydrogen at high pressure, a share of energy of the order of $10 \%$ of the original hydrogen energy content is needed, while liquefaction consumes about $30 \%$, even if some new more efficient process under study can provide better figures. This issue invests also hydrides where energy is required to absorb/de-absorb hydrogen. In this case however it is quite hard to provide figures on the required energy as such storage technologies are not yet completely mature and therefore indications on energy requirements can be unreliable.

Figure 2. Status of Various Hydrogen Storage Technologies. Learning demo values are average data across more than 90 vehicles tested under real conditions in the framework of the DoE Hydrogen Program.

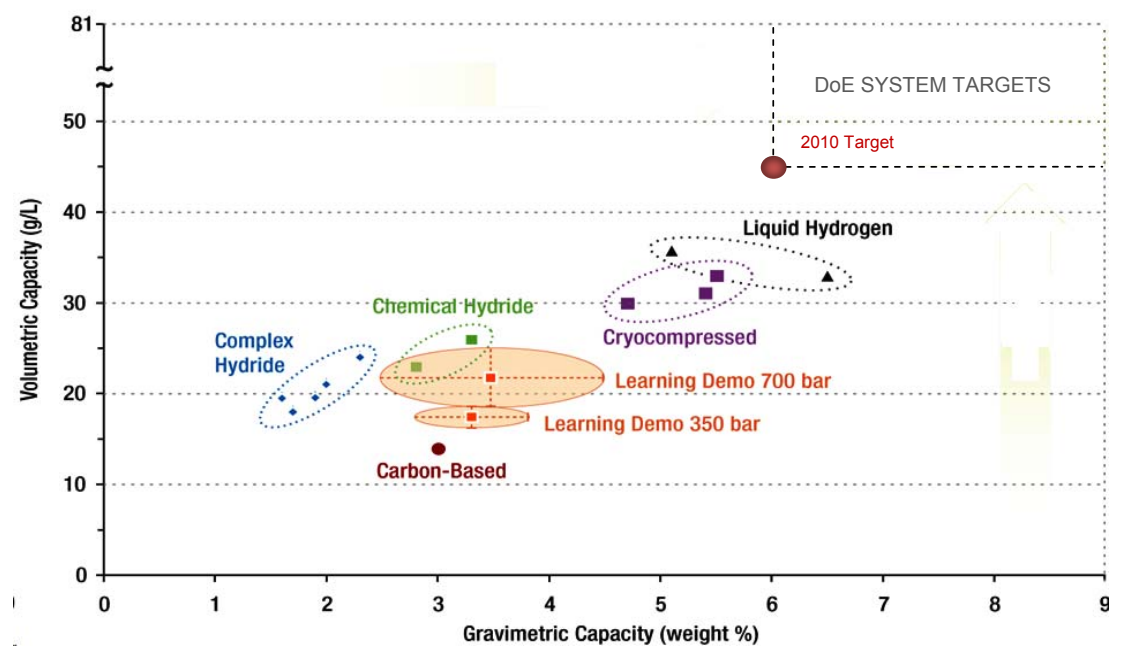

\subsection{Hydrogen Transport and Distribution}

The use of hydrogen as energy carrier requires its availability at large scale and at the point of utilization, for a variety of applications. Infrastructures for transport and distribution, very different depending on the hydrogen production process (fossil or non fossil sources, centralized or on-site plant) are therefore needed. To date the hydrogen is distributed as compressed gas or in liquid form.

Compressed hydrogen can be transported by pipelines (for industrial uses there are more than 700 $\mathrm{km}$ of pipeline in USA and almost 1,600 km in Europe, normally operating at pressures of 10-20 bar) or on road by trucks (able to transport from 2,000 to 6,200 $\mathrm{m}^{3}$ - about 150-500 $\mathrm{kg}$ - of hydrogen at 200-350 bar) when quantities and distances are small. A few projects are also evaluating the possibility to use the existing gas pipelines to transport mixture of natural gas/hydrogen.

Hydrogen in liquid form (cooled below $-253^{\circ} \mathrm{C}$ ) has a density higher than gas (about 800 times, at atmospheric pressure); therefore a cryogenic tank truck is able to transport a hydrogen liquid amount that is considerably higher than a gaseous hydrogen tube trailer (50,000 liters correspond to about 3,700 kg, i.e. almost 10 times). 
The problem of hydrogen transport is closely linked to the distribution to the point of use and, particularly, to the possible configuration of the hydrogen filling stations. Over 200 filling stations are operational or under construction in the world in the framework of the current demonstration projects. There are different lay-outs (Figure 3): some of them supply only gaseous hydrogen, in others liquid hydrogen is available, both as an intermediate storage for subsequent gasification and for direct use.

Some so-called "Total Energy" stations have also been realized, in which on-site production of hydrogen is integrated with an electric energy and heat generation system (usually a fuel cell). Different studies have indicated such solution as the most efficient option, at least in the short-medium term.

From an economical point of view, the transport by pipeline seems to be the most suitable option, even if it requires very high investments for the infrastructures (between 500 and 1,500 k€/km). In general, it is estimated that transport and distribution imply, in case of centralized generation, about 5$10 € / \mathrm{GJ}$ of additional costs to the hydrogen production.

The problem of the availability of transport and distribution infrastructures is very critical for hydrogen development; even if their growth could be gradual, as function of the demand, it will be necessary to provide infrastructures in advance, to allow an easy diffusion of hydrogen vehicles and other applications.

Figure 3. Possible Layout for Hydrogen Refueling Station.

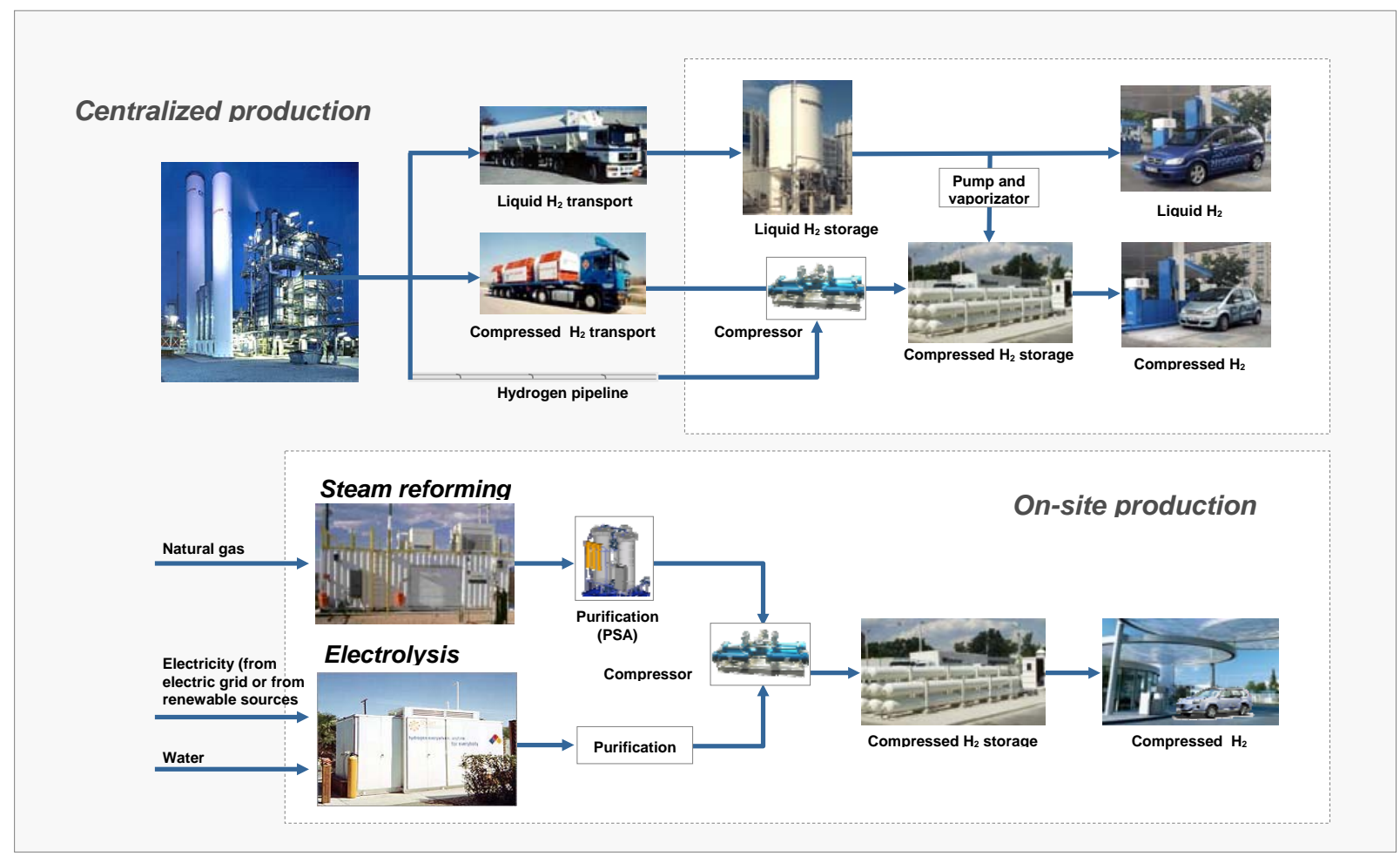

Some European studies [15] have estimated that the necessary investments for the infrastructure implementation able to satisfy a vehicle penetration of 5\% in the Europe only by 2020 is of the order of 20-35 B€, while the creation in Europe of infrastructures necessary to support the full deployment of hydrogen vehicles by 2050 will require a total investment quantifiable as 700-2,200 B€ [16]. 


\subsection{Hydrogen utilization}

Hydrogen, in addition to the traditional industrial applications, can be used both in transport (internal combustion engines and, above all, fuel cells) and in stationary power generation (thermal cycles and fuel cells) sectors.

\subsubsection{Hydrogen Vehicles}

Hydrogen use in transport allows to obtain zero (with fuel cells) or very reduced (with internal combustion engines) emissions at local level and, depending on the source used for hydrogen production, can give a significant contribution to the reduction of vehicle greenhouse gas emissions (Figure 4).

Figure 4. Greenhouse Gas Emissions - Well-to-Wheels Analysis. ENEA elaboration on CONCAWE/EUCAR source [17].

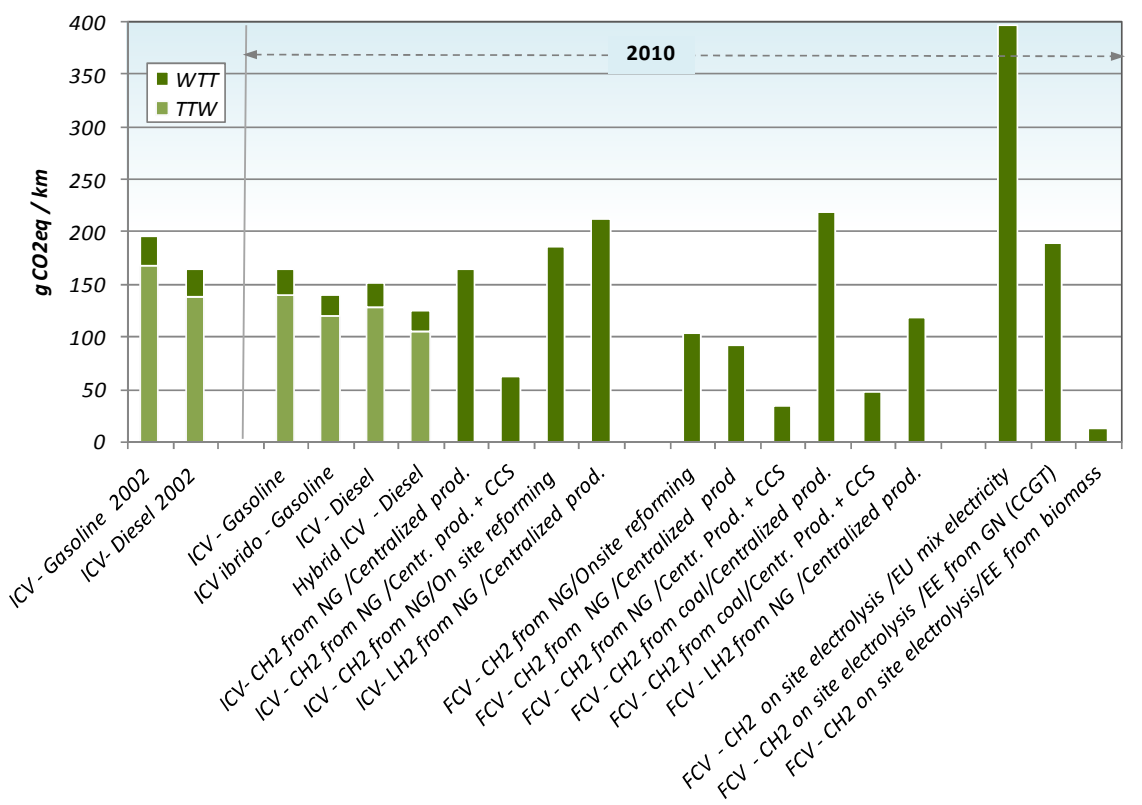

\section{Internal Combustion Engines}

Vehicles using internal combustion engines (ICE) can operate both with pure hydrogen or hydrogen-natural gas blends. Significant experiences on the use of hydrogen have been carried out with modified conventional engines.

To exploit the potential advantages of hydrogen at the best it is however necessary that engines are designed taking into account its characteristics as fuel (wide flammability range in comparison with other fuels, low ignition energy and almost double flame rate). The main car manufacturers are confident that the realization of hydrogen engines is feasible using the currently available technologies, once the boundary conditions (creation of fuelling infrastructures, development of regulations and standards) allow to generate a sufficient market volume. 
Testing ICE vehicles (cars or buses) fed with hydrogen has been carried out or is in progress in USA and Europe, even if the commitment is significantly lower than for fuel cell vehicles. Car manufactures such as BMW, Ford Motors and Mazda are involved in the development of hydrogen-fed ICE technology.

Another solution under evaluation contemplates the use of blends of natural gas and hydrogen (HCNG), at variable content of hydrogen, but in any case not higher than $30 \%$ by volume, to avoid engine modifications. The hydrogen addition to natural gas, although at low percentages, has positive effects on engine operation, reducing exhaust emissions, not only due to the substitution of the carbon with hydrogen, but also because its presence allows a more complete and rapid combustion, with a significant efficiency increase [18].

Both solutions (pure hydrogen and HCNG) can represent an interesting development area in the short term, for the environmental benefits that they allow; hydrogen ICE technology can also contribute to promote an early diffused hydrogen use and the construction of fuelling infrastructures.

\section{Fuel Cell Vehicles}

The use of fuel cells systems powered with hydrogen represents one of the most promising options in the medium-long term for the development of efficient and environment-friendly means of transport, as the use of hydrogen implies zero emissions at local level. Besides fuel cell vehicles offer efficiencies almost two times higher than conventional vehicles, maintaining similar performances in terms of driving range, top speed and acceleration.

Among the various fuel cell types, the polymer electrolyte fuel cells (PEFC) are the most suitable technology for transport applications, being characterized by low operation temperature, high power density, quick start-up and rapid response to load changes.

In the last decade, the governments of the most industrialized countries have started R\&D programs in this field, investing several million dollars, and major auto manufacturers are actively engaged in fuel cell vehicle development and demonstration, with high resource commitments (it is estimated that Daimler and General Motors have invested more than 1 billion dollars in the last years). Some car industries (General Motors, Honda, Nissan and Toyota) have in-house programs to produce their own fuel cell stacks, while others (Daimler AG, Ford Motor) prefer to make supply agreements with fuel cell developers such as Ballard Power Systems, UTC Power or Nuvera Fuel Cells. The objectives of the main international programs are shown in Table 4.

Despite substantial progresses, short-medium term R\&D efforts are still necessary before fuel cell vehicles become widely available and achieve significant market share. It is needed, in fact, to overcome a number of technical and economic barriers. In addition to the availability of a wide hydrogen transport and distribution network and reliable and safe technologies to store it on-board of vehicles, it is necessary to reach a stack durability of about 5,000 hours and a good reliability, but above all to achieve costs compatible with the transport market. Being the cost of an ICE of 20-30 $€ / \mathrm{kW}$, a fuel cell system to be competitive should cost less than $30-50 € / \mathrm{kW}$. Today, with low volumes of production and components built through manual fabrication processes, costs are around 2000-3000 $€ / \mathrm{kW}$. These costs are highly dependent on the number of vehicles on the road. 
Table 4. Fuel Cells for Transportation. Objectives of main programs ${ }^{\text {a }}$

\begin{tabular}{|c|c|c|c|c|c|c|c|}
\hline & \multicolumn{3}{|c|}{ USA (DoE) } & \multicolumn{3}{|c|}{ Japan (NEDO) } & European \\
\hline & $\begin{array}{c}\text { Status } \\
2006\end{array}$ & 2010 & 2015 & $\begin{array}{c}\text { Status } \\
2007\end{array}$ & 2010 & 2015 & 2015 \\
\hline Efficiency & $59 \%$ & $60 \%$ & $60 \%$ & $50 \%$ & $60 \%$ & $60 \%$ & $>45 \%$ \\
\hline Durability & $2,000 \mathrm{~h}$ & $5,000 \mathrm{~h}$ & $5,000 \mathrm{~h}$ & $2,000 \mathrm{~h}$ & $3,000 \mathrm{~h}$ & $5,000 \mathrm{~h}$ & $\begin{array}{l}5,000 \text { h car } \\
10,000 \text { h bus }\end{array}$ \\
\hline Cost & $\begin{array}{r}107 \$ / \mathrm{kW} \\
(72 € / \mathrm{kW}) \\
\quad(\text { projec }\end{array}$ & $\begin{array}{r}45 \$ / \mathrm{kW} \\
(30 € / \mathrm{kW}) \\
\text { tions are for } \\
\text { units/year) }\end{array}$ & $\begin{array}{l}30 \$ / \mathrm{kW} \\
(20 € / \mathrm{kW}) \\
00,000\end{array}$ & - & $\begin{array}{l}330 € / \mathrm{kW} \\
(100,000 \\
\text { units/year) }\end{array}$ & $\begin{array}{c}67 € / \mathrm{kW} \\
(1,000,000 \\
\text { units/year) }\end{array}$ & $\begin{array}{c}100 € / \mathrm{kW} \\
\text { (150,000 } \\
\text { units/year) }\end{array}$ \\
\hline
\end{tabular}

$$
\text { a } 1 €=1.5 \$ ; 1 €=160 ¥
$$

Cost analyses carried out from TIAX (in collaboration with Argonne National Laboratory, under the DoE Hydrogen, Fuel Cells and Infrastructures Program)[19], show for $80 \mathrm{~kW}$ fuel cell vehicle power systems, with current technology and high volume production, estimated costs of $39 € / \mathrm{kW}$. Figure 5 (left side) shows that almost half (54\%) of system cost is represented by the cost of stack manufacture, which is strongly influenced by the electrode and platinum costs. On the right side instead the incidence of the different stack components is provided, where electrodes represent more than $50 \%$ of the cost. However the opinion of cell developers is that DoE targets are difficult to be reached by 2015.

Figure 5. Estimated PEFC System and Stack Cost (Transport application).ENEA elaboration on DoE source[19].

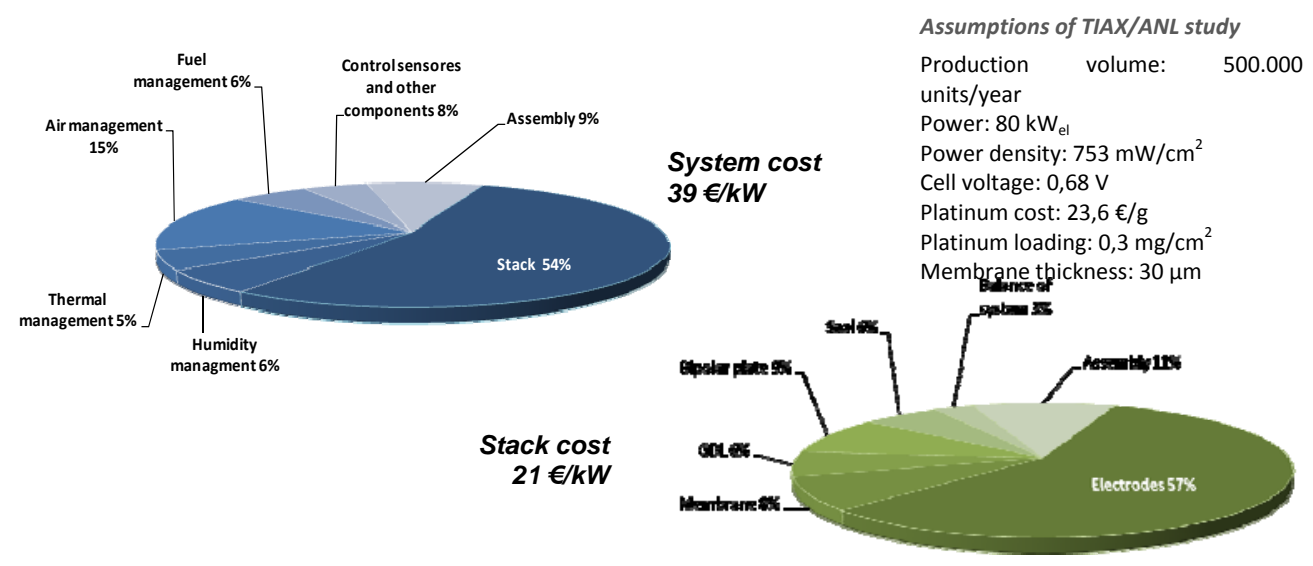

2.4.2. Hydrogen in the electric generation

Hydrogen can be used both in large size centralized power plants based on thermal cycles and in distributed energy generation with fuel cells. 


\section{FUEL CELLS}

A fuel cell is an electrochemical device that converts chemical energy of a fuel directly into electrical energy and heat. Due to such direct energy conversion, the efficiency of fuel cells is not limited by the Carnot cycle; they can therefore, in principle, obtain higher efficiencies than conventional power generation systems.

A single fuel cell consists of two catalyst-coated electrodes (anode and cathode) separated by an electrolyte. The hydrogen or a hydrogen-rich fuel is fed into the anode, the oxygen (air) enters at the cathode. At the anode the hydrogen is dissociated into hydrogen ions and electrons. The electrons flow to the cathode through an external circuit, creating an electric current. At the cathode, hydrogen ions combine with oxygen and electrons from the external circuit, producing water and heat.

Depending on the type of fuel cell, the ions that migrate through the electrolyte will be different $\left(\mathrm{H}^{+}\right.$for PEFC and PAFC, $\mathrm{CO}_{3}{ }^{=}$in $\mathrm{MCFC}, \mathrm{O}^{-}$in SOFC, $\mathrm{OH}^{-}$In $\mathrm{KOH}$ ).

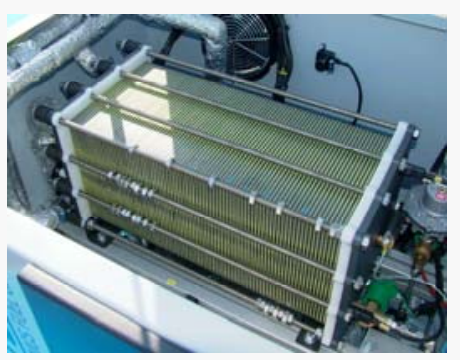

A single cell produces usually a voltage of about $0.6-0.7 \mathrm{~V}$ and currents between 300 and $800 \mathrm{~mA} / \mathrm{cm}^{2}$, therefore, for practical applications a sufficient number of individual cells is connected in series, through bipolar plates, to form the so-called fuel cell "stack". More stacks are then assembled in modules to obtain generators with the desired electrical power.

There are different fuel cell technologies with different characteristics and stage of development. Fuel cells are, in general, classified according to the type of employed electrolyte (polymer electrolyte fuel cell, phosphoric acid fuel cells, molten carbonate fuel cells, solid oxide fuel cells, alkaline fuel cells);in addition, there are direct methanol fuel cells which directly use a methanol aqueous solution as fuel.

\begin{tabular}{|c|c|c|c|c|c|c|}
\hline & $\begin{array}{c}\text { Alkaline } \\
\text { Fuel Cell } \\
\text { (AFC) }\end{array}$ & $\begin{array}{l}\text { Polymer } \\
\text { Electrolyte } \\
\text { Fuel Cell } \\
\text { (PEFC) }\end{array}$ & $\begin{array}{c}\text { Direct } \\
\text { Methanol Fuel } \\
\text { Cell } \\
\text { (DMFC) }\end{array}$ & $\begin{array}{l}\text { Phosphoric Acid } \\
\text { Fuel Cell } \\
\text { (PAFC) }\end{array}$ & $\begin{array}{l}\text { Molten Carbonate } \\
\text { Fuel Cell } \\
\text { (MCFC) }\end{array}$ & $\begin{array}{l}\text { Solid Oxide } \\
\text { Fuel Cell } \\
\text { (SOFC) }\end{array}$ \\
\hline Electrolyte & $\begin{array}{l}\text { Potassium } \\
\text { hydroxide }\end{array}$ & $\begin{array}{l}\text { Polymeric ion } \\
\text { exchange } \\
\text { membrane }\end{array}$ & $\begin{array}{l}\text { Polymeric ion } \\
\text { exchange } \\
\text { membrane }\end{array}$ & Liquid phosphoric acid & $\begin{array}{l}\text { - Lithium/potassium } \\
\text { carbonate }\end{array}$ & $\begin{array}{l}\text { Yttria stabilized } \\
\text { zirconia }\end{array}$ \\
\hline Temperature & $60-120^{\circ} \mathrm{C}$ & $70-100{ }^{\circ} \mathrm{C}$ & $70-100{ }^{\circ} \mathrm{C}$ & $160-220^{\circ} \mathrm{C}$ & - $600-650^{\circ} \mathrm{C}$ & $900-1000{ }^{\circ} \mathrm{C}$ \\
\hline $\begin{array}{l}\text { Electric } \\
\text { efficiency }\end{array}$ & $60 \%$ & $35-60 \%$ & $25-40 \%$ & $40-50 \%$ & $45-55 \%$ & $45-60 \%$ \\
\hline $\begin{array}{l}\text { Technology } \\
\text { status }\end{array}$ & $5-100 \mathrm{~kW}$ & $<1-250 \mathrm{~kW}$ & $<2 \mathrm{~kW}$ & Plants up to $11 \mathrm{MW}$ & -50 kW-3 MW & $1-200 \mathrm{~kW}$ \\
\hline Applications & $\begin{array}{c}\text { Portable power } \\
\text { Transport } \\
\text { space and military uses }\end{array}$ & $\begin{array}{l}\text { Residential systems } \\
\text { Backup power } \\
\text { Portable power } \\
\text { Transport }\end{array}$ & $\begin{array}{c}\text { Portable power } \\
\text { Consumer electronics }\end{array}$ & $\begin{array}{l}\text { Distributed } \\
\text { generation } \\
\text { Cogeneration }\end{array}$ & $\begin{array}{l}\text { - Distributed generation } \\
\text {-Industrial cogeneration }\end{array}$ & $\begin{array}{c}\text { Distributed generation } \\
\text { Cogeneration } \\
\text { Transport (APU) }\end{array}$ \\
\hline Advantages & - High energy density & $\begin{array}{l}\text { - Low operating } \\
\text { temperature } \\
\text { - Quick start-up } \\
\text { - High energy } \\
\text { density } \\
\text { - Absence of } \\
\text { corrosive } \\
\text { components }\end{array}$ & $\begin{array}{l}\text { - Low operating } \\
\text { temperature } \\
\text { - Direct use of fuel }\end{array}$ & $\begin{array}{l}\text { - High efficiency in } \\
\text { cogeneration } \\
\text { - } \mathrm{CO}_{2} \text { tolerance }\end{array}$ & $\begin{array}{l}\text { - High-grade waste heat } \\
\text { available for } \\
\text { cogeneration/ } \\
\text { trigeneration uses } \\
\text { - Internal reforming } \\
\text { possibility }\end{array}$ & $\begin{array}{l}\text { - High-grade waste } \\
\text { heat available for } \\
\text { cogeneration or in } \\
\text { bottoming cycles } \\
\text { - Internal reforming } \\
\text { possibility }\end{array}$ \\
\hline Disadvantages & $\begin{array}{l}\text { - High sensitivity to } \\
\text { impurities ( } \mathrm{CO} \text { e } \\
\left.\mathrm{CO}_{2}\right)\end{array}$ & $\begin{array}{l}\text { - Complex water } \\
\text { management } \\
\text { - Low co tolerance } \\
\text { - Use of high cost } \\
\text { catalysts }\end{array}$ & $\begin{array}{l}\text { - Crossover } \\
\text { problems } \\
\text { - Low density } \\
\text { power }\end{array}$ & $\begin{array}{l}\text { - Use of high cost } \\
\text { catalysts } \\
\text { - Corrosive nature } \\
\text { of phosphoric acid } \\
\text { - High } \\
\text { manufacturing cost }\end{array}$ & $\begin{array}{l}\text { - Degradation of cell } \\
\text { components due to } \\
\text { corrosive nature of } \\
\text { electrolyte } \\
\text { - High start-up time }\end{array}$ & $\begin{array}{l}\text { - High start-up time } \\
\text { - Problems of } \\
\text { component } \\
\text { mechanical } \\
\text { stability and } \\
\text { durability }\end{array}$ \\
\hline
\end{tabular}

* For AFC and PEFC the higher efficiency values are referred to systems fuelled with pure hydrogen 
In the last few years some initiatives have been undertaken to develop combined-cycle gas turbine plants with pre-combustion (Pre-combustion is the process that allows $\mathrm{CO}_{2}$ removal prior of combustion. Such process is quite efficient, allowing the capture up to $90-95 \%$ of $\mathrm{CO}_{2}$ emissions) $\mathrm{CO}_{2}$ separation. These plants, particularly promising for coal gasification, allow the production of a hydrogen-rich synthesis gas and its utilization for electric energy generation in combined cycles. Such systems, also promising for the combined production of electricity and hydrogen, require significant modifications of the turbines (particularly on the burners), in addition to a considerable development and demonstration effort for the processes related to coal gasification and $\mathrm{CO}_{2}$ separation and sequestration.

It is however reasonable to expect that, once feasibility and acceptability of $\mathrm{CO}_{2}$ sequestration have been demonstrated, such plants will have an important role in the electric generation and, indirectly, in the hydrogen market.

Fuel cells are considered a key technology in a future economy based on hydrogen, as they are able to convert this energy carrier in a very efficient way. Each type of fuel cell has its own advantages and limitation (see box). Stationary fuel cell systems, with a capacity ranging from a few $\mathrm{kW}$ to some MW, can be used for back-up power, distributed power generation and cogeneration or for portable generators.

Fuel cells are not yet a commercial technology and a considerable effort in research and development is on going to meet the efficiency, durability and cost targets required to gain significant market shares and be fully accepted by consumers [20]. In particular, in stationary applications lifetime should reach 40,000-60,000 hours (the present values ranging from 2,000-3,000 hours for PEFC to 30,000-40,000 for PAFC). At present, depending on the type of technology, the capital costs range from 2,500-3,000 €/kW (PAFC) to 8,000-12,000 €/kW (SOFC); a significant reduction is needed in the medium-term, to reach the target of $1,000-1,500 € / \mathrm{kW}$. Results of DoE/SECA Phase 1 program suggest that, assuming production volumes of $250 \mathrm{MW} / \mathrm{yr}$, the manufacturing cost of 3-5 $\mathrm{kW}$ SOFC systems could be less than $650 € / \mathrm{kW}[21]$.

\section{Prospects for development of hydrogen and fuel cells}

Hydrogen and fuel cells are, in general, technologies for the medium-long term. Their role in the energy system depends on many factors, technical and non-technical, and in general on their capability to satisfy requirements of energy and environmental type in a more effective and suitable way than possible competing solutions.

\subsection{The Non-technical Barriers}

The main non-technical barriers to be overcome for the development of hydrogen and fuel cells are briefly described in this section.

\section{Political Barriers}

The development of hydrogen is able to provide $\mathrm{CO}_{2}$ emission reduction and increase of the energy supply security. As a consequence, hydrogen extra-costs can be accepted, in a medium-long term 
perspective, only where strong energy and environmental policies are enacted. These policies have been studied by different organizations. In particular, IEA has analyzed many energy scenarios, where the political attitude to foster more benign energy technologies has been investigated, using as more relevant parameter the incentives to reduce $\mathrm{CO}_{2}$ emissions, expressed as $\$ / \mathrm{t}$ of $\mathrm{CO}_{2}$ equivalent. The results of these IEA forecasts [7] show that, under high political commitment, i.e. with $100 \$ / t \mathrm{CO}_{2}$, hydrogen can play a significant role in the energy market, reaching about $30 \mathrm{EJ} /$ year by 2050. Instead, with only $25 \$ / t \mathrm{CO}_{2}$, the hydrogen impact will be limited only to $10 \mathrm{EJ} /$ year. In absence of any $\mathrm{CO}_{2}$ incentives the demand for hydrogen remains negligible up to 2050.

\section{Economical Barriers}

They are essentially linked to the cost of hydrogen (and therefore its production and distribution) and fuel cells, which should reach values competitive with those of other fuels and technologies. For hydrogen the cost for the end user should not exceed, in perspective, $2 € / \mathrm{kg}$ (about $17 € / \mathrm{GJ}$ ), while fuel cells should come to cost less than $30-50 € / \mathrm{kW}$ for traction and 1,000-1,500 €/kW for stationary uses.

\section{Infrastructural Barriers}

The implementation of infrastructures that make hydrogen available for different applications represents one of the main barriers for large scale hydrogen use. It is therefore essential to promote gradual growth of the infrastructure, selecting suitable measures to support the huge investments required.

\section{Code and Standards Barriers}

The availability of standards and regulations, currently in the first phase of definition, is an essential condition for a wide utilization of hydrogen and fuel cells, in order to guarantee a high standard of safety in all the phases of hydrogen cycle.

\section{Social Barriers}

Hydrogen and some of its related technologies (such as for example CCS) have acceptability issues from the users and, more in general, the public opinion; they are to be faced and overcome by means of suitable actions of technology demonstration and user formation and information.

\subsection{Competing Technologies}

Hydrogen and fuel cells should compete, both in terms of fuels and of conversion technologies, with many alternative solutions, that are also in a position to positively contribute to emission reduction and diversification of energy sources. For the transport applications, the main competing solutions to take into account are biofuels, synthetic fuels and electric vehicles (both battery-driven and hybrids); such solutions also present limitations and problems, but all of them have, with respect to hydrogen, the advantage of not requiring a completely new transport and distribution infrastructure. For what concerns fuel cells stationary applications for distributed generation and cogeneration, the 
competing options are, on one hand, the availability of electric energy produced from "zero emission" coal, renewable and nuclear plants and, on the other hand, technologies such as microturbines, internal combustion and Stirling engines, etc. fed with conventional fuels. Finally, hydrogen use as a mean to store electric energy, above all from renewable sources, should compete with other systems, such as batteries, potentially more efficient and economical.

Currently initiatives have also been started from EU [22] and US [23] focusing on the use of renewable energy sources (RES) and the adoption of biofuels in the transport sector. In particular, EU is promoting the so called 20-20-20 Directive which will impose by $202020 \%$ of $\mathrm{CO}_{2}$ emission reduction, $20 \%$ increase of energy efficiency and a RES share of $20 \%$, of which at least $10 \%$ in the transport sector, while US is fostering a large use of biofuels, whose consumption should reach 36 billion of gallons, i.e. about 115 Mtoe by 2022 (as reference it can be indicated that the US oil demand for all the final uses was about 930 Mtoe in 2006). At the moment it is unclear if these initiatives can help or curb the hydrogen development. In fact, the use of biofuels will presumably act as a negative factor, while on the other end a larger RES use in electricity production could have positive repercussions on hydrogen, as large share of RES electricity will imply energy storage. In fact, RES electricity cannot be easily produced on the basis of the demand. This has minimum effects for low RES shares, but when they increase energy storage becomes necessary to absorb the production excess and to make it available under higher demand conditions. Hydrogen can be used as storage medium, but it will have to compete for instance with batteries. However, a comparative analysis between hydrogen and its potential competitors cannot be carried out very easily, also considering that quite a lot of such technologies are under development. In any case it is quite clear that, in the long term, when effective and economical technologies will be fully available, RES and hydrogen can probably have important connections. At that time hydrogen can become the best commodity for RES conversion. But at that time hydrogen technologies need to be fully available, as consequence of initiatives that have promoted hydrogen in a short-medium term. Without them long term solutions cannot be pursued. It is therefore required to develop an integrated energy strategy which avoids uneven conflicts between almost mature and in progress technologies, but is able to sustain the long term energy options up to a level where they can compete in the energy market. At that time, provided that all the economic and environmental constraints are satisfied, the market will select the most adequate energy options.

\subsection{Possible Hydrogen Penetration Scenarios}

In the last years many studies [7,24-25] have tried to outline possible scenarios for hydrogen development as an energy carrier. A synthesis of the results of these studies was provided by the European Roads2HyCom project [26]. All the analyses show that hydrogen will be able to have a significant role in the energy system on condition of strong environmental policies, high fossil fuel costs and adequate improvement of the involved technologies.

For hydrogen applications, the scenarios do not take into consideration its use in the electric power generation, which could have an important role, in connection with the use of IGCC plants with $\mathrm{CO}_{2}$ sequestration. However this possibility will only increase the importance of hydrogen in the energy market, strengthening its role. 
In the envisaged scenarios, the road transport sector will use about $75 \%$ of hydrogen. The main technology will be fuel cells vehicles, even if ICE vehicles will have a significant market share, especially at the beginning. The first vehicles will be introduced in the public transport fleets, both for technical reasons (reduced problems for on-board storage and distribution infrastructures), and because their wide-scale use could be supported from public contributions, on the basis of their environmental benefits. Niche markets (small electric vehicles, forklifts, boats) will have an important role in the first phase as they will be able to contribute to the cost reduction and the creation of the distribution network. A significant introduction in the private car market is not envisaged before 2020 (at such time the European Platform assumes a market share between 1 and 3\%).

As an example of the analyses, the results of the HyWays project [25] scenarios related to the hydrogen vehicle introduction, with reference to the European situation, are shown. Figure 6 illustrates four possible HyWays scenarios, based on different assumptions about the evolution of technology and the supporting policies carried out. In 2050 the most optimistic scenario shows that hydrogen vehicles represent about $75 \%$ of the passenger cars, while in more conservative scenarios the hydrogen share will be not higher than $30 \%$.

Figure 6. Scenarios of Hydrogen Vehicle Penetration for Passenger Transport [25].

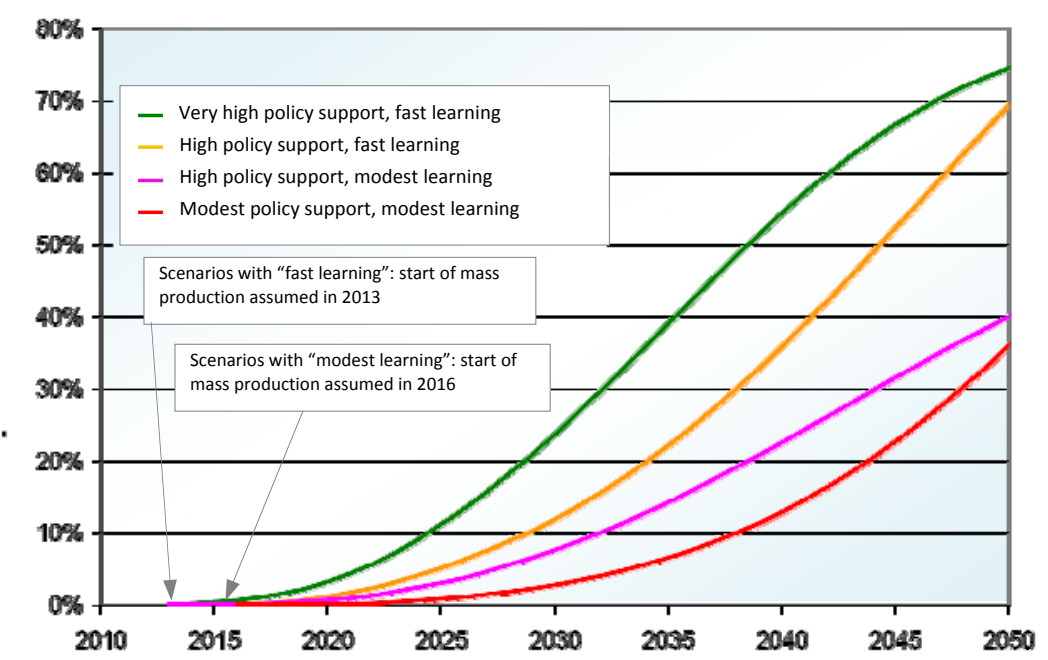

With regards to the production of hydrogen, in the first years the hydrogen available as byproduct of industrial processes and/or produced in small size distributed systems (based on reforming of natural gas and electrolysis from the electric grid) will be used. After 2020 there will be an increase of the centralized production from natural gas and coal with $\mathrm{CO}_{2}$ sequestration, while beyond 2030 the production from renewables (wind with electrolysis, biomass gasification, thermochemical cycles fed with solar energy) will also become significant. The forecasts for 2050 are different enough among the available studies, above all for what concerns the share of hydrogen still produced from fossil fuels, that changes between 10 and $80 \%$; in the first case the main primary sources will be renewables (50\%) and electrolysis from nuclear (40\%). The evaluation of the total hydrogen demand in 2050 ranges for Europe between 2.1 and 5.3 EJ/year and, at world level, between 12.4 and 39.4 EJ/year [26]. Such values are low compared to the foreseen total energy demand, which will be, by that time, $785 \mathrm{EJ} /$ year. In any case the share of hydrogen will be important, considering it is used mainly in the transport 
sector. The possible mix of hydrogen production in Europe among 2020 and 2050, estimated from HyWays on the basis of the visions of the different member states, is found in Figure 7. The share produced from renewables should reach $30 \%$ in 2050.

Figure 7. Hydrogen production mix for the 10 EU Member States based on the national visions [25].

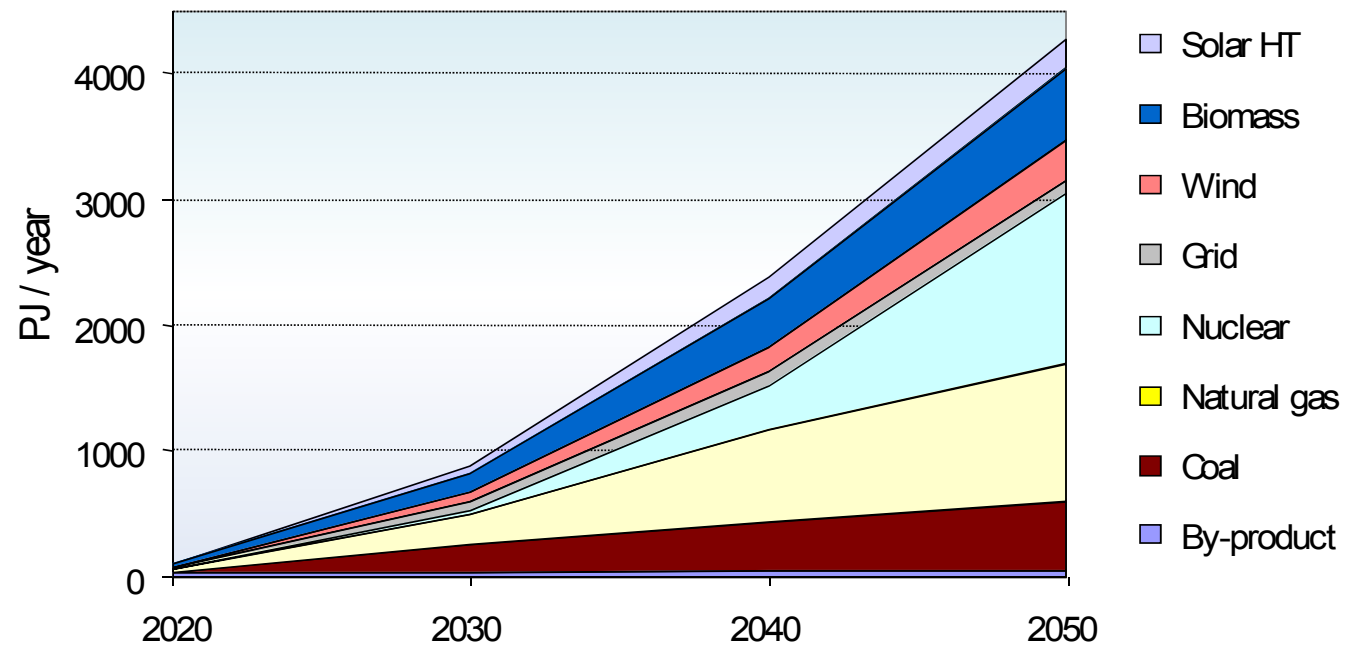

For what concerns particularly the Italian situation, a first evaluation of the possible penetration of hydrogen vehicles has been carried out, on the basis of the National Platform document [27]; the expected scenario is shown in Figure 8 where it is compared with the high and low penetration scenarios provided by HyWays. In 2050 a fleet of 15 million hydrogen vehicles is forecast for Italy, with a yearly consumption of hydrogen equal to about 13 Mtoe (less than $4 \mathrm{Mt} / \mathrm{year}$ of hydrogen). The possible production mix is found in Figure 9 that shows, also for our country, a renewable share of the order of $30 \%$.

Figure 8. Comparison of Italian platform and HyWays forecasts on hydrogen vehicle penetration.

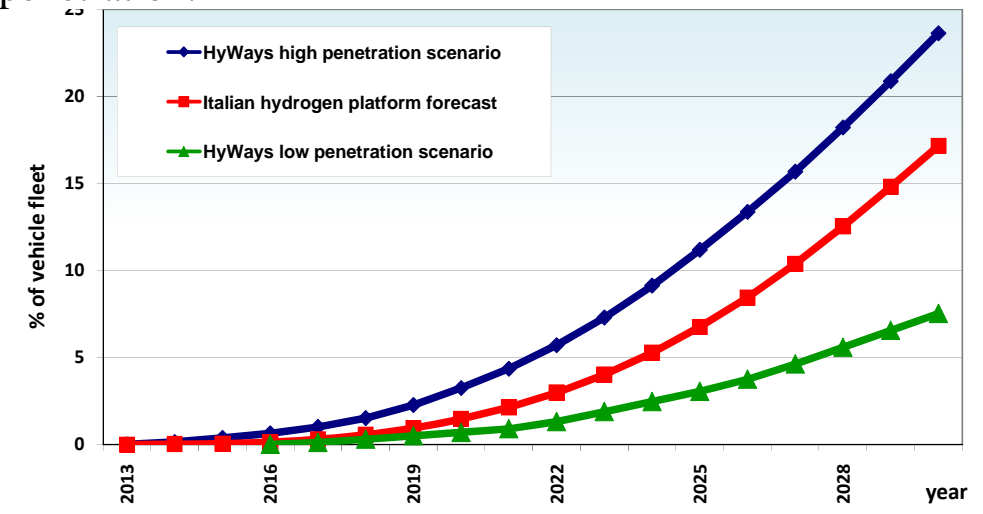


The hydrogen directly used in centralized electric energy production plants has to be added to such production, as coal gasification technology will have a considerable role by that time, ultimately increasing the hydrogen energy share.

Figure 9. HyWays Annual Hydrogen Production Forecast for Italy. ENEA elaboration on HyWays source [25].

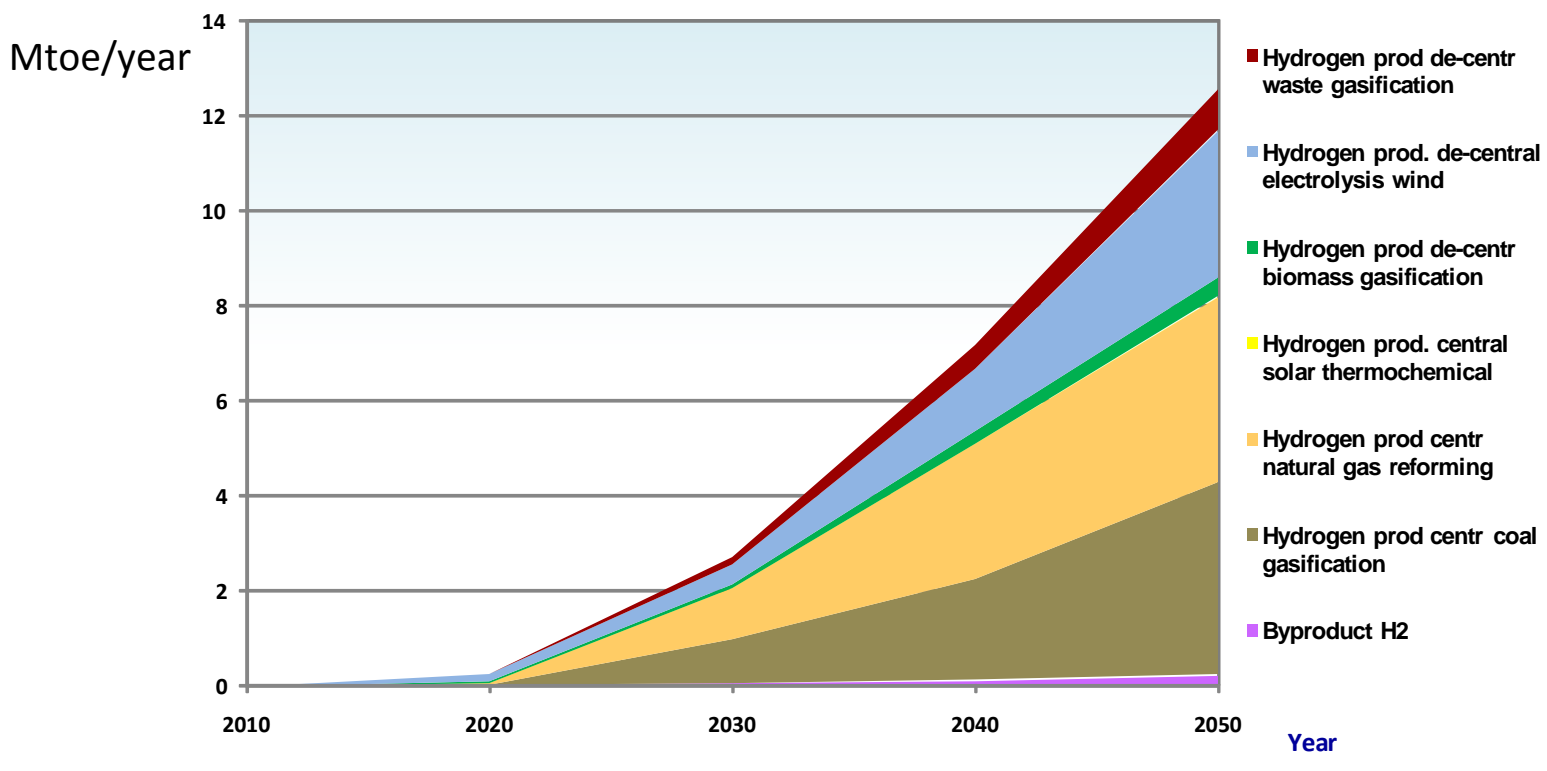

\section{International Programs}

Important programs for hydrogen and fuel cells are in progress in the main industrialized countries (more than $800 \mathrm{M} €$ /year from public financings only, of which $250 \mathrm{M} €$ in Japan and at least the same in the United States), with the involvement of many industries, research structures and stakeholders. Objective of these programs is to overcome the main technological and non technological barriers that prevent the development of reliable and competitive technologies and their introduction in the market in the medium term. The involved themes essentially concern sustainable hydrogen production (from renewable sources or fossils with CCS), transport and distribution infrastructures, on-board vehicle storage, cost and durability of the fuel cells, development of an adequate regulation framework.

The research programs of the European Commission are of special importance; besides funding many projects in the field of the hydrogen and fuel cells (about $300 \mathrm{M} €$ in the Sixth Framework Program), they have promoted in the last years the growth of European expertise in this field. In particular the Joint Technology Initiative on Fuel Cells and Hydrogen (FCH-JTI) [28,29], a public private partnership, has started in June 2008. The European Commission will fund $470 \mathrm{M} €$ for the period 2008-2013 and at least an equivalent contribution will be provided by the private sector. The main goal of the JTI is to speed up the development of fuel cells and hydrogen technologies in Europe and enable their commercialization between 2010 and 2020.

In addition to the European Commission and Industry Grouping, about 50 research structures (associate in Research Grouping) are participating in this initiative. In figure 10 [30], the shares of the investments are shown; it can be seen that most of the funds are dedicated to demonstrations (52\%). 
Figure 10. FCH-JTI Budget Breakdown (action category and application area) [30].

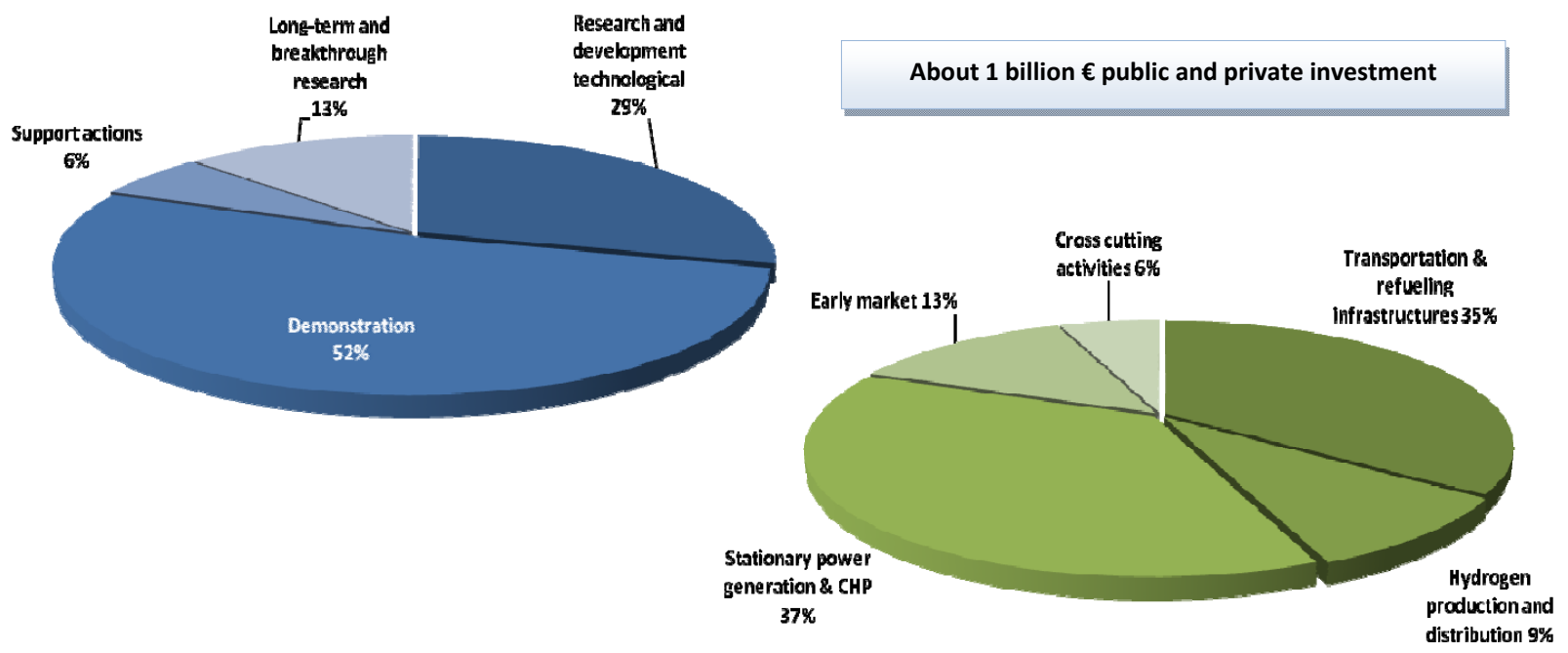

\section{The Italian Framework on Hydrogen and Fuel Cells}

\subsection{National Programs}

The growing interest for the hydrogen technologies has created in Italy the conditions for industries and public authorities to start several RD\&D initiatives. The most important research program is jointly financed by the Ministry of Education, University and Research and the Ministry of Environment, with the launch, in 2005, of a specific research program on hydrogen and fuel cells through the Special Integrative Fund for Research (FISR; 8 projects on hydrogen and 6 on fuel cells, with total financings of $90 \mathrm{M} €$ of and total costs of $125 \mathrm{M} €$ for a three year period).

Specific projects have been promoted by the Ministry of Environment and Regions (Piedmont, Lombardy, Veneto, Emilia Romagna, Tuscany, Lazio, Abruzzi, Apulia and Sicily). In addition the Ministry of Economic Development, in the framework of the "Industria 2015” Program [31], provides financing for innovative researches on hydrogen and fuel cells under the "Energy Efficiency" and "Sustainable Mobility" thematic areas.

The present activities at national level involve several research organizations (ENEA, CNR Institutes, CESI Research and universities) covering most of hydrogen topics (i.e. production processes; materials and systems for storage, transport and distribution; conversion technologies such as thermal cycles and internal combustion engines; fuel cells systems; safety issues).

Many Italian industries are involved in the hydrogen activities, in particular:

- for fuel cell, Exergy Fuel Cells (PEFC), Ansaldo Fuel Cells (MCFC) and SOFCPower (SOFC) are developing stacks and systems; other industries are developing fuel cell components (De Nora Industries, FN) or systems (Electro Power Systems, ICI Caldaie, MTS, TurboCare);

- in the transportation area, Fiat Group, through CRF, has developed several prototypes of hydrogen vehicles (buses and cars) and is testing a fleet of Panda Hydrogen under specific projects promoted by Local Authorities; other activities are carried out by PIEL, Micro-Vett and Piaggio; 
- in the hydrogen production and distribution fields, oil companies (ENI) and industrial gas providers (Sapio, SOL and others) are active; power companies (ENEL and Edison) are testing fuel cell systems and carrying out development activities for hydrogen production from coal and use of hydrogen or hydrogen rich gas in turbine plant.

The Italian activities on hydrogen imply, on the whole, a remarkable commitment (50-60 M€/year). To facilitate the coordination of these initiatives and strengthen the links with the European programs, the Ministry of Education, University and Research has also established in 2005 an Italian Platform on Hydrogen and Fuel Cells with the aim to define a national strategy in this field and identify the most promising technologies to be developed for hydrogen deployment. The first draft document has been issued, but, due to the delays in its approval, there is the need to update it before starting its application.

\subsection{The ENEA Program}

ENEA is the Italian agency operating in the fields of energy, environment and new technologies to support the country's competitiveness and sustainable development. ENEA has been involved for a long time in the field of hydrogen and fuel cells, in the framework of the initiatives carried out to face the challenges of emission reduction, diffusion of renewable sources and increase of energy efficiency. In particular, the agency's effort is focused on some of the key technologies (such as production from fossil and renewable sources, materials and systems for storage, fuel cells), providing high level expertise for their development and demonstration.

\subsubsection{Production from fossil sources}

The possibility to produce hydrogen in sustainable way from fossil fuels, particularly from coal, is an essential element for its widespread use in the medium-long term. Moreover, sustainable production from fossil fuels is closely tied to the development of "zero emission" generation systems that have a strategic importance both at international and Italian level. Such technologies will benefit from industrial collaborations and important financings, in order to overcome the present critical issues for $\mathrm{CO}_{2}$ sequestration. In particular, the development of "zero emission" coal generation systems is one of the main ENEA activities and includes, among other objectives, also the cogeneration of electric energy and hydrogen. This is presently carried out through the "Clean Coal" Project, which involves, in the short-medium term, the design, construction and testing of a pilot plant, with pre-combustion $\mathrm{CO}_{2}$ capture, at Sotacarbo research center (Carbonia, Sardinia). Even if the project activities are essentially directed to electric energy generation, with hydrogen mainly used in the plant, the feasibility demonstration of hydrogen production from coal is also essential for its use in other applications (Figure 11). The plant, that can also use biomass, together with coal, provides a hydrogenrich gas (syngas), which allows an easier separation of the main compounds $\left(\mathrm{CO}_{2}\right.$ and $\left.\mathrm{H}_{2}\right)$ and removal of the impurities. 
Figure 11. Lay-out of the Sotacarbo Pilot Plant.

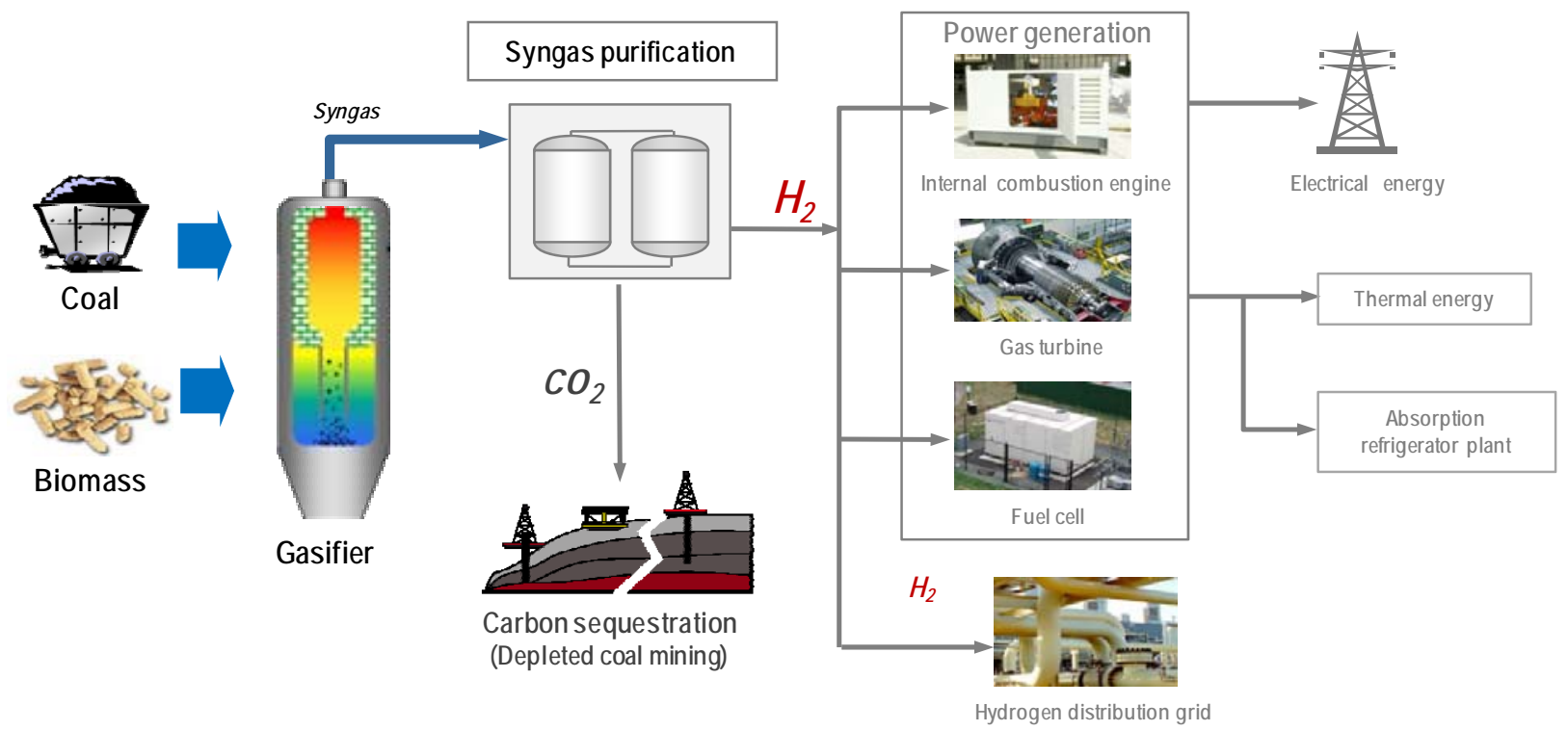

\subsubsection{Production from Renewables}

The ENEA activities in this field are devoted to the development of advanced processes, such as thermochemical cycles, biomass gasification and biological fermentation, that have very promising application prospects in the long term, but still require considerable R\&D effort and present high risks in their development route. The activities are carried out in the frame of the FISR Program, mostly through collaborations with research structures. The planning of future activities will be decided at the end of the Program (2009) on the basis of the results, in particular for most advanced chains such as thermochemical cycles and biological fermentation processes. The planning analyses should also interest R\&D efforts for short-medium term technologies, such as electrolysis devices connected to renewable production (i.e. electrolysis using electric energy from wind and photovoltaics), considered the strongly emphasis put on this subject at European level and the possible synergies with fuel cells activities.

\section{Production from biomasses}

Biomass gasification process, producing syngas, has been developed at the Trisaia Center in the South of Italy (Figure 12). In particular, a $500 \mathrm{~kW}_{\text {th }}$ pilot gasification plant is available in the Centre and will be coupled, after gas purification, with a molten carbonate fuel cell stack of $125 \mathrm{~kW}$ for hydrogen utilization. For what concerns hydrogen production through anaerobic digestion of organic substances, ENEA activity is focused on the study of specific micro-organisms, with the aim to better understand the whole process at laboratory level and to acquire elements for scale up.

\section{Production from water by means of thermochemical cycles fed by solar energy}

The activities presently involve two thermochemical processes (sulfur-iodine and manganese ferrite process, Figure 13). For the first one the different cycle reactions have been analyzed and 
demonstrated experimentally. ENEA is proceeding in this phase to design a laboratory scale plant that will be the first one in Europe to provide a continuous production of about $10 \mathrm{NL} / \mathrm{h}$ of hydrogen. The test results, if positive, will foster the design of a pilot plant of $2000 \mathrm{Nm}^{3} /$ day.

Figure 12. Trisaia $500 \mathrm{~kW}_{\text {th }}$ Pilot Plant (Biomass steam gasification).

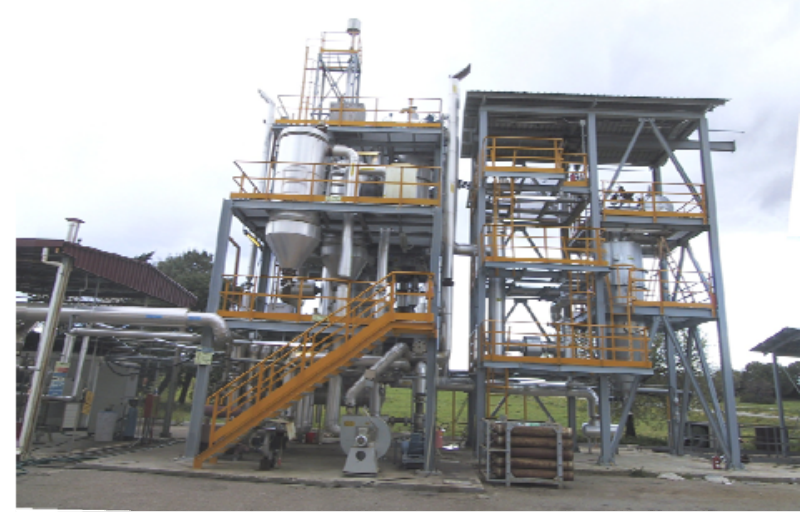

Figure 13. Conceptual Scheme of a Hydrogen Production Plant Using Concentrating Solar Collectors.

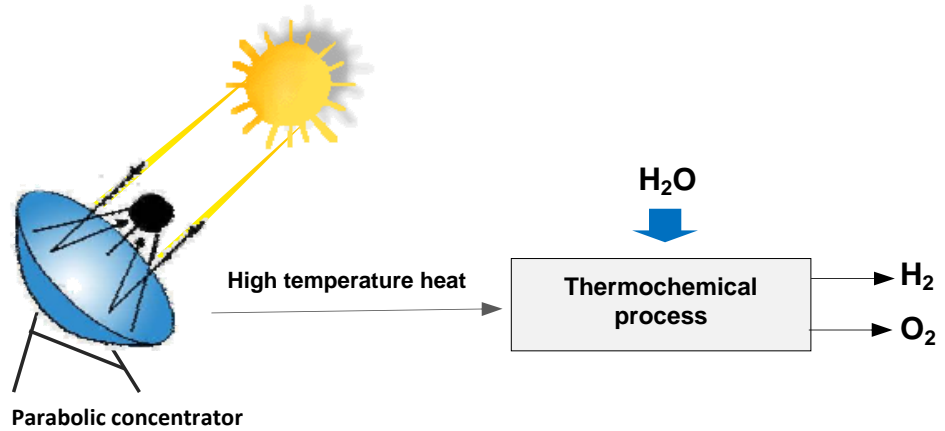

For what concerns the manganese ferrites, the activities are focused on the selection of the most effective methods for the production of ferrites, to be used in solar reactors. The thermochemical processes, once their viability is demonstrated, will allow practically infinite hydrogen production, as they will just need water and thermal energy, while the other chemical components will be recreated at the end of the cycle.

\subsubsection{Material and systems for storage}

Storage is also a particularly critical subject both at materials and systems level. ENEA is carrying out R, D\&D activities on advanced technologies for the storage of hydrogen with metal and chemical hydrides and other advanced materials, aimed at improving basic performances of the storage systems in terms of energy density, reliability and safety. In particular ENEA is studying polymeric composites and micro-composites, based on $\mathrm{LaNi}_{5}$, and micro and nano composites, based on $\mathrm{Mg}$, with the target to overcome the technological limits of current solutions (pressurized tanks, liquid hydrogen, and hydrides). Besides, activity is carried out on the usage of chemical hydrides, such as sodium 
borohydride. The activities are related to all the aspects of the cycle, including materials, components, prototype design and engineering, characterization and testing of complete storage systems with dedicated testing facilities.

\subsubsection{End Uses}

Fuel Cells

ENEA has a considerable expertise and test facilities on fuel cells, particularly on PEFC and MCFC, and important collaborations with industrial and research structures both at national and European level. This is relevant in the light of the FCH-JTI that assigns high priority to the development of these technologies, both for vehicle applications and cogeneration.

At the moment, the main ENEA activities are carried out in the frame of research programs financed by the Ministry of Education, University and Research and the Ministry of Economic Development and are mainly concerned with the development of new materials and cell components and the development and testing of small-scale systems (Figure 14).

Figure 14. PEFC test facility (Casaccia Research Center).

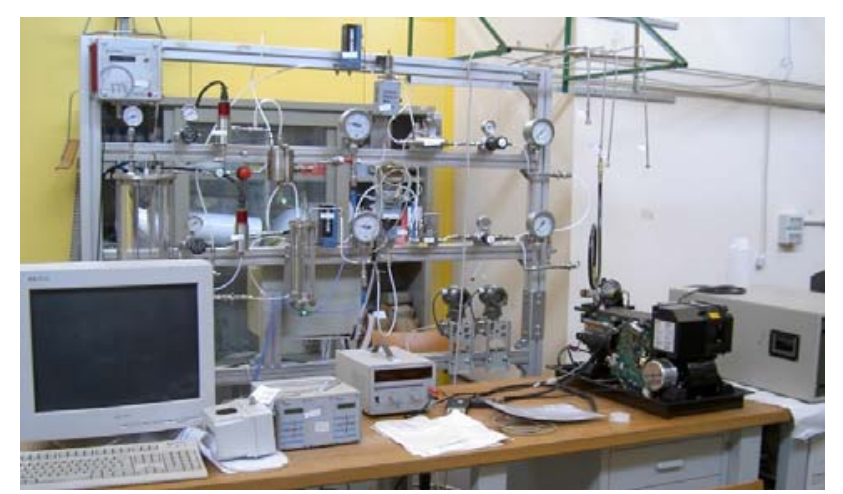

Such activities are focused, for PEFC, on the development of components such as catalysts, electrodes, membranes and their integration in the cell and testing of fuel cell stacks of different sizes (less than $5 \mathrm{~kW}$ power). For MCFC, instead, the main activities are related to cell components (cathodes, bipolar plates, etc.) and system development. An important effort is devoted to the construction of a $125 \mathrm{~kW}$ fuel cell plant at the Trisaia center, which will be fuelled by hydrogen rich gas from biomass (Figure 12), and of a facility to test the coupling for hybrid fuel cell/turbine.

\section{Hydrogen Vehicles}

This application has, at international and European level, the highest priority and most of the research resources are allocated to it. ENEA is participating in component development (especially electric components) and vehicle testing through its laboratories and test facilities. In particular ENEA, in the framework of the $6^{\text {th }} \mathrm{FP}$, contributed to the definition of preliminary rules and standards (HARMONHY Project [32]) and is involved in a project for fuel cell vehicle development (HYSYS [33]). Different activities have been carried out at national level, with testing of hydrogen vehicles 
(IRISBUS fuel cell bus for the municipal transport authority of Turin, NEO light duty vehicle developed by Microvett) and characterization of hydrogen and natural gas blends in ICE vehicles (NG buses of Ravenna Transport Company).

The increasing attention on hydrogen application, especially from Local Authorities, is creating a favorable framework for demonstrations and requires the collection and integration of the results in order to avoid duplications and waste of resources. This is one of the tasks that ENEA can cover, especially in the light of the present opportunities, both at national (Industria 2015, Region financings) and European (JTI calls) level. In spite of the limited commitment from Italian industries, this could also positively increase the presence of ENEA in the specific field, considering that a very important task for hydrogen success is the transfer of the information to public and new stakeholders.

\section{Conclusions}

The paper has addressed the main aspects related to the possible role of hydrogen in future society in order to foster the development of a sustainable energy system. Hydrogen, in fact, can contribute positively to face the present challenges on climate change and energy supply security, being able to provide reduction of atmospheric emissions, both at global and local level, diversification of primary energy sources and industrial opportunities.

Considering the hydrogen prospects, ENEA, the Italian energy agency, is heavily committed to create the right framework in the national context to proceed toward a future, where hydrogen can play a relevant role in the energy system. To this end ENEA is carrying out activities on the main research aspects considering all parts of the entire hydrogen chain, from production to end uses, applying criteria that privilege the processes with the best chances to be selected in our country. In this sense ENEA is also trying to stimulate Italian stakeholders, i.e. industry, decision makers, academic institutes, etc. to be more active, often joining them in specific researches.

On the other side, although technical and economic aspects are important for hydrogen deployment, it has to be underlined that they are not sufficient for the success of its technologies. In fact, as hydrogen technologies have been introduced mainly to face environmental and energy security issues, just lowering hydrogen costs could not be enough. The reason is that the environmental and energy security aspects can hardly be handled through merely economical penalties, although this approach has been chosen in the past, imposing a cost for $\mathrm{CO}_{2}$. The only application of penalties could be misleading as they should be calculated taking into account the costs to be incurred to recover from the negative effects provided by a bad use of energy resources. However, if the degradation is not stopped soon, certain critical planetary conditions could be largely violated and there would be no chance to really recover from climate change related effects, even allocating very large resources. Therefore hydrogen deployment should be worthwhile only if other measures and criteria are promoted (i.e. better use of energy resources, increase of energy efficiency, decreasing non essential activities, etc.). Even in this case the effect will be really successful only if the new approach is pursued in conjunction with important changes of present human behavior, especially considering the most developed countries. It is therefore required that human beings modify their present life style substantially, privileging collective advantages instead of personal ones, to allow a large penetration of hydrogen and more benign technologies. This change is of course very complex and will require long and highly 
coordinated actions to be undertaken. Policy makers should take the lead among all the stakeholders providing suitable measures to foster hydrogen deployment and creating the conditions to increase public awareness through education, formation and information.

It is clear at the end that hydrogen can be successfully deployed in the future only if a radical change is achieved of the way energy is perceived in human life. This means that the importance of energy for growth of society is fully understood by most of the citizens. More attention on importance of energy could also lead to important changes in the way energy is presently produced, distributed and consumed. Under this aspect hydrogen could play a significant role not only in transport applications, but also in residential and commercial uses. In fact hydrogen, especially if converted in fuel cells, can provide end users with locally produced electric energy and heat, modifying the present situation where a centralized electricity production is privileged. In this way consistent advantages in energy efficiency and environmental safeguard can be achieved in the long term, i.e. whenever the hydrogen transition will be positively completed.

\section{Acronyms}

$\begin{array}{ll}\text { AFC } & \text { Alkaline fuel cell } \\ \text { CEA } & \text { Atomic Energy Commission } \\ \text { CCS } & \text { Carbon capture and storage } \\ \text { CCGT } & \text { Combined Cycle gas turbine } \\ \text { CH2 } & \text { Compressed Hydrogen } \\ \text { CIEMAT } & \text { Centro de Investigaciones Energéticas } \\ \text { CRF } & \text { Fiat Research Center } \\ \text { DLR } & \text { German Aerospace Center } \\ \text { DMFC } & \text { Direct methanol fuel cell } \\ \text { DoE } & \text { Department of Energy } \\ \text { EE } & \text { Electric energy } \\ \text { FP } & \text { Framework Programme } \\ \text { GDL } & \text { Gas diffusion layer } \\ \text { ICE } & \text { Internal combustion engine } \\ \text { NG } & \text { Natural gas } \\ \text { FCH- JTI } & \text { Fuel Cell and Hydrogen Joint Technology Initiative } \\ \text { FCV } & \text { Fuel cell vehicle } \\ \text { HCNG } & \text { Hydrogen/natural gas blend } \\ \text { ICV } & \text { Internal combustion engine vehicle } \\ \text { LH2 } & \text { Liquid hydrogen } \\ \text { LHV } & \text { Lower heating value } \\ \text { MCFC } & \text { Molten carbonate fuel cell } \\ \text { MIUR } & \text { Ministry of Education, University and Research } \\ \text { MSE } & \text { Ministry of Economic Development } \\ \text { MTS } & \text { Merloni Termosanitari } \\ \text { PAFC } & \text { Phosphoric acid fuel cell } \\ \text { PSA } & \text { Pressure swing adsorption } \\ \text { PEFC } & \text { Polymer electrolyte fuel cell } \\ \text { SMR } & \text { Steam methane reforming } \\ \text { SECA } & \text { Solid State Energy Conversion Alliance } \\ & \end{array}$




$\begin{array}{ll}\text { SOFC } & \text { Solid oxide fuel cell } \\ \text { TTW } & \text { Tank-To-Wheels } \\ \text { UT-3 } & \text { University of Tokyo Cycle -3 } \\ \text { WTT } & \text { Well-to-Tank }\end{array}$

\section{References}

1. Galli, S.; Calò, E.; Monteleone, G. Idrogeno da idrocarburi; RT ENEA 2008 (in Italian).

2. Mueller, L.F.; Tzimas. E.; Kaltschmitt. M.; Peteves, S. Techno-economic assessment of hydrogen production processes for the hydrogen economy for the short and medium term. Int. J. Hydrogen Energ. 2007, 32, 3797-3810C.

3. Padrò. C.E.G.; Putsche. V. Survey of the Economics of Hydrogen Technologies; Technical report NREL/ TO-570-27079, 1999; Available online: http://www1.eere.energy.gov/hydrogenandfuel cells/ hydrogen_publications.html.

4. Watkiss, P.; Hill, N. The Feasibility, Costs and Markets for Hydrogen Production; AEA Technology, Final Report, Sep. 2002.

5. Hypogen Pre-feasibility Study; Final Report prepared by ENEA, Fraunhofer ISI and Risoe National Laboratory, EUR 21512 EN, January 2005; Available online: http://ie.jrc.ec.europa.eu/ publications/ scientific_publications/2005/EUR21512EN.pdf.

6. Cemmi, A.; Pozio, A. Processo di elettrolisi dell'acqua per la produzione di idrogeno: Stato dell'arte e applicazioni tecnologiche; RT ENEA 2008 (in Italian).

7. Prospects for Hydrogen and Fuel Cells; International Energy Agency, OECD Publishing: Paris, France, December 2005. Available online: http://www.iea.org/textbase/nppdf/free/2005/ hydrogen2005.pdf.

8. Izzo, G.; Camerini, M.; Gambacorta, A.; Migliore, G.; Signorini, A.; Varrone C. Produzione biologica di idrogeno: stato delle conoscenze e prospettive, Progetto Nazionale FISR Vettore Idrogeno, Giornata di Studio, Oct. 20, 2006 (in Italian).

9. Giaconia, A.; Tarquini, P.; Vignolini, M. Cicli termochimici di idrolisi per la produzione di idrogeno. Energia, Ambiente e Innovazione 2006, 3, 58-74 (in Italian).

10. Schultz K. R., Use of the Modular Helium Reactor for Hydrogen Production, World Nuclear Association, Annual Symposium 2003.

11. Perret, R. Development of Solar-Powered Thermochemical Production of Hydrogen from Water; DOE Hydrogen Program, Annual Progress Report, FY 2007.

12. Lanchi, M.; Sau, S.; Tarquini, P.; Varsano, F.; Vignolini, M. Produzione dell’idrogeno dall’acqua mediante processi termochimici. Energia, Ambiente e Innovazione 2007, 4, 40-53 (in Italian).

13. Hydrogen, Fuel Cells and Infrastructure Technologies Program Multi-Year RD\&D Plan, U.S. Department of Energy, Oct. 2007; Available online: http://www.eere.energy.gov/ hydrogenandfuelcells/mypp/.

14. Milliken, A.; Satyapal, S.; Smith, B.; Stanford, J. DoE Hydrogen Program Overview. In Proceeding 2008 Fuel Cell Seminar \& Exposition, Phoenix, Arizona, Oct. 27 - 30, 2008; Available online: http://fcse.confex.com/fcse/2008/webprogram/Session1013.html 
15. An investigation into the H2 5\% 2020 target of the European Commission; NOVEM-TU Wien, Cleaner Drive Project, June 2004.

16. Techno-economic assessment of hydrogen transmission \& distribution systems in Europe in the medium and long term; Report EUR 21586 EN-JRC Petten, Mar. 2005.

17. Well-to-wheels analysis of future automotive fuels and powertrains in the European Context; CONCAWE, EUCAR, EC DG JRC, Dicembre 2005 e Versione 2c March 2007.

18. Ortenzi, F.; Chiesa, M.; Scarcelli, R.; Pede, G. Experimental tests of blends of hydrogen and natural gas in light-duty vehicles. Int. J. Hydrogen Energ. 2008, 33, 3225-3229.

19. Sinha, J.; Lasher, S.; Yang, Y.; Kopf, P. Direct Hydrogen PEMFC Manufacturing Cost Estimation for Automotive Applications. In Annual Merit Review Proceedings, Arlington, Virginia, May 1518, 2007; pp. 9-13.

20. Ronchetti, M. Celle a Combustibile. Stato di sviluppo e prospettive della tecnologia, ENEA, Jan. 2008; Available online: http://www.enea.it/produzione_scientifica/volumi/V2008_02_celle comb.html (in Italian).

21. 2007 Fuel Cell Program Annual Report, DOE/NETL-2007/1288, Aug. 2007, http://www.fossil.energy.gov/programs/powersystems/fuelcells/.

22. European Parliament legislative resolution on the Proposal for a Directive of the European Parliament and of the Council on the promotion of the use of energy from renewable sources, (COM) 2008, 0019, T6-0609/2008; Available online: http://www.europarl.europa.eu/.

23. National Biofuels Action Plan, Biomass Research and Development Board, October 2008; Available online: http://www1.eere.energy.gov/biomass/

24. World Energy Technology Outlook 2050: WETO-H2, EU 22038, 2006.

25. HyWays, The European Hydrogen Roadmap, 2007; Available online: http://www.hyways.de

26. Snapshots of Hydrogen Uptake in the Future. A Comparison Study, Road2HyCom Project, September 2007; Available online: http://www.roads2hy.com.

27. Piattaforma Nazionale Idrogeno e Celle a combustibile, Indirizzi strategici per la Ricerca e Sviluppo, September 2005 (in Italian).

28. European Hydrogen and Fuel Cell technology Platform. Available online: https://www.hfpeurope.org/.

29. European Industry Grouping for a Fuel Cell and Hydrogen Joint Technology Initiative, Available online: http://www.fchindustry-jti.eu/.

30. Martin, A. The Multi-Annual Implementation Plan, Fuel Cell and Hydrogen General Stakeholders Assembly-Launch of the FCH Joint Undertaking 2008, October 2008, Brussels.

31. Industria 2015 Program. Available online: http://www.industria2015.ipi.it/.

32. HarmonHY Project. Available online: http://www.harmonhy.com/.

33. HySYS Project. Available online: http://www.hysys.de/.

(C) 2009 by the authors; licensee Molecular Diversity Preservation International, Basel, Switzerland. This article is an open-access article distributed under the terms and conditions of the Creative Commons Attribution license (http://creativecommons.org/licenses/by/3.0/). 